\title{
Projections of mid-century summer air-quality for North America: effects of changes in climate and precursor emissions
}

\author{
J. Kelly ${ }^{1, *}$, P. A. Makar ${ }^{1}$, and D. A. Plummer ${ }^{2}$ \\ ${ }^{1}$ Air Quality Research Division, Environmental Science and Technology Branch, Environment Canada, \\ 4905 Dufferin Street, Toronto, Ontario, Canada \\ ${ }^{2}$ Canadian Centre for Climate Modelling and Analysis, Environment Canada, Victoria, British Columbia, Canada \\ * now at: Golder Associates, 2390 Argentia Road, Mississauga, Ontario, L5N 5Z7, Canada
}

Correspondence to: P. A. Makar (paul.makar@ec.gc.ca)

Received: 23 December 2011 - Published in Atmos. Chem. Phys. Discuss.: 3 February 2012

Revised: 18 May 2012 - Accepted: 28 May 2012 - Published: 22 June 2012

\begin{abstract}
Ten year simulations of North American current and future air-quality were carried out using a regional airquality model driven by a regional climate model, in turn driven by a general circulation model. Three separate summer scenarios were performed: a scenario representing the years 1997 to 2006, and two SRES A2 climate scenarios for the years 2041 to 2050. The first future climate scenario makes use of 2002 anthropogenic precursor emissions, and the second applied emissions scaling factors derived from the IPCC Representative Concentration Pathway 6 (RCP 6) scenario to estimate emissions for 2050 from existing 2020 projections. Ten-year averages of ozone and $\mathrm{PM}_{2.5}$ at North American monitoring network stations were used to evaluate the model's current chemical climatology. The model was found to have a similar performance for ozone as when driven by an operational weather forecast model. The $\mathrm{PM}_{2.5}$ predictions had larger negative biases, likely resulting from the absence of rainwater evaporation, and from sub-regional negative biases in the surface temperature fields, in the version of the climate model used here.

The differences between the two future climate simulations and the current climate simulation were used to predict the changes to air-quality that might be expected in a future warmer climate, if anthropogenic precursor emissions remain constant at their current levels, versus if the RCP 6 emissions controls were adopted. Metrics of concentration, human health, and ecosystem damage were compared for the simulations. The scenario with future climate and current anthropogenic emissions resulted in worse air-quality than for current conditions - that is, the effect of climate-change
\end{abstract}

alone, all other factors being similar, would be a worsening of air-quality. These effects are spatially inhomogeneous, with the magnitude and sign of the changes varying with region. The scenario with future climate and RCP 6 emissions for 2050 resulted in an improved air-quality, with decreases in key pollutant concentrations, in acute human mortality associated with air-pollution, and in sulphur and ozone deposition to the ecosystem. The positive outcomes of the RCP 6 emissions reductions were found to be of greater magnitude than the negative outcomes of climate change alone. The RCP 6 scenario however resulted in an increase in the deposition of nitrogen, as a result of increased ammonia emissions expected in that scenario, compared to current ammonia emissions levels.

The results of the study raise the possibility that simultaneous reductions of greenhouse gases and air pollution precursors may further reduce air pollution levels, with the added benefits of an immediate reduction in the impacts of air pollution on human and ecosystem health. Further scenarios to investigate this possibility are therefore recommended.

\section{Introduction}

Global climate change occurs through changes in the balance of incoming and outgoing radiation in the complete climate system, and may manifest itself as alterations in the mean and statistical distribution of meteorological parameters such as temperature, wind speed and direction, humidity, and precipitation at the regional and local scale (IPCC, 2007). These 
variables, in turn, impact gas phase and aerosol chemistry, transport, cloud processing of gases and aerosols, and emissions and deposition. Climate change may thus affect the formation and distribution of both ozone $\left(\mathrm{O}_{3}\right)$ and particulate matter (PM), two key indexes for air quality. Gases and aerosols may also affect climate, by interacting with the incoming (solar) and outgoing (terrestrial) radiation.

Climate change impacts on air quality noted in the literature include: (1) an increase in temperature causing an increase in water vapour concentrations: both water vapour and temperature changes affect chemical reaction rates; (2) a change in the spatial and temporal distribution of meteorological conditions: local changes in weather patterns giving rise to changes in air quality; (3) modifications to global circulation dynamics, resulting in changes to the distribution of pollutants; (4) changes to the emissions of natural precursor gases, which are meteorologically driven; and (5) decreased cloudiness, resulting in enhanced photochemical smog production (Jacob and Winner, 2009; Hogrefe et al., 2004; Leung and Gustafson, 2005; Dawson et al., 2007; Liao et al., 2006; Stevenson et al., 2006; Steiner et al., 2006; Forkel and Knoche, 2006). A more comprehensive review of climate change and air quality is provided in Kelly et al. (2012); a summary is provided below.

The most comprehensive projections of future climate rely on global or regional scale numerical models of the climate system based on fundamental physical principles (CMOS, 2007). Projected changes in climate resulting from the use of these global models can be related to regional air quality indicators through downscaling, either statistical or dynamical. Demuzere and van Lipzig (2010a) provide an overview of the many different approaches to statistical downscaling. These approaches are easily implemented, computationally inexpensive, and flexible, but are predicated on the assumption that the current climate statistical relationships between predictors and predictands will remain valid in a future climate, and the assumption of no change in emissions, transport or chemical formation processes (Demuzere and van Lipzig, 2010a, b; Timbal et al., 2009; Wise, 2009). In dynamical downscaling, global scale climate information at a coarse resolution is used to drive a higher resolution regional model which is run over a limited area, and may involve General Circulation Models (GCMs; resolution of a few hundreds of kilometers), global Chemical Transport Models (CTMs), Regional Climate Models (RCMs; resolution of a few tens of kilometres, simulating up to a single continent) and regional CTMs. Global climate and chemistry models (cf. Liao et al., 2004; Mickley et al., 2004a, b; Brasseur et al., 2006; Stevenson et al., 2006; Wu et al., 2007) have insufficient spatial resolution to resolve atmospheric, chemical, and surface processes used for assessing regional air quality (Leung and Gustafson, 2005). Regional-scale models are required to prevent $\mathrm{O}_{3}$ underestimates in urban areas and overestimates in background areas (Racherla and Adams, 2008), capture concentration spikes (Forkel and Knoche, 2006), and capture spatial distributions in emissions, land cover, dispersion and concentrations (Liao et al., 2006).

Regional modelling studies have shown that areas experiencing high $\mathrm{O}_{3}$ concentrations under the current climate are usually predicted to experience an increase of 1 to $6 \mathrm{ppbv}$ in average daily maximum $8-\mathrm{h} \mathrm{O}_{3}$ concentration ( $\left.\mathrm{md} 8 \mathrm{hrO} 3\right)$ in the future. A large portion of this increase is often attributed to changes in biogenic emissions, associated with changes in temperature and surface photosynthetically active radiation (Hogrefe et al., 2004; Civerolo et al., 2007; Forkel and Knoche, 2006; Murazaki and Hess, 2006; Steiner et al., 2006; Bell et al., 2007; Jacob and Winner, 2009). A complicating factor in this regard is the timing and the extent to which the spatial distribution of hydrocarbon-emitting vegetation may change in response to a changing climate (Chen et al., 2009a, b; Lam et al., 2011; Wu et al., 2008a, b; Fiore et al., 2011). Local conditions such as the emissions of other $\mathrm{O}_{3}$ precursors also have a significant effect on local $\mathrm{O}_{3}$ production (Forkel and Knoche, 2006; Bell et al., 2007). Changes to precursor emissions have a larger impact on $\mathrm{O}_{3}$ production than variations in meteorology associated with climate change (Racherla and Adams, 2009; Jacobson and Streets, 2009; Lin et al., 2010;, Kawase et al., 2011; Lam et al., 2011). In addition to interannual variability and the specifics of projected changes in physical climate at the regional scale, the effects of model resolution, boundary conditions, and chemical mechanisms as all contribute to the spread in projected changes in ozone (Avise et al., 2009; Racherla and Adams, 2008; Wu et al., 2008b; Forkel and Knoche, 2007). Despite these variations, the general consensus indicates that the eastern US and parts of Europe will see an increase in the md8hrO3 under the IPCC A and B scenarios (IPCC, 2007). Areas with high pollution are expected to see increases in this metric, while rural areas are expected to see minimal impacts or decreases (Jacob and Winner, 2009).

The impact of future climate change on $\mathrm{PM}_{2.5}$ is an emerging area of study (Liao et al., 2006, 2007; Racherla and Adams, 2006; Tagaris et al., 2007, 2008; Avise et al., 2009; Wise, 2009), with most studies reporting increases in aerosol species components or aerosol burden (cf. Liao et al., 2006). Many studies link variations in aerosol projections with future precipitation (Jacob and Winner, 2009; Racherla and Adams, 2006).

Accounting for interannual variability is essential to GCM-CTM studies and may have contributed to some of the above-mentioned inter-model variability in projections of future air-quality. Racherla and Adams (2008) found it necessary to use five years or more of simulation data in order to separate the effects of future climate change and interannual variability on ozone episodes in the eastern United States. Leung and Gustafson (2005) used $10 \mathrm{yr}$ periods to avoid interannual climate variations that might otherwise obscure long term trends.

While the studies described above focus on changes in ambient concentrations or related metrics, regional air-quality 
models are capable of providing projections on other aspects of the impacts of air pollution. For example, regional models may be used to estimate the potential damage to ecosystems and impacts on crop yields through estimating spatial varying levels of acidifying deposition (cf. Makar et al., 2009) and ozone deposition (Engardt, 2008; Van Dingenen et al., 2009; Stella et al., 2011). The human-health impact of air pollution is one of the main drivers behind research in this field, with potentially substantial health effects resulting from climatechange-induced changes in air-quality (Sheffield et al., 2011; Chang et al., 2010; Tagaris et al., 2009, 2010; Cheng et al., 2009; Jackson et al., 2010). Global financial losses due to reductions in crop yields resulting from ozone deposition are expected to reach between $\$ 1$ billion to $\$ 17$ billion, depending on the emissions scenario employed (Averny et al., 2011). The estimated global annual health costs due to ozone pollution by 2050 are expected to be $\$ 580$ billion US, with mortalities due to acute exposure exceeding 2 million (Selin et al., 2009).

A more comprehensive review of the current state of climate - air-quality modelling may be found in Kelly et al. (2012).

In the work described below, a regional climate model was used to downscale a general circulation model's climate, and the resulting meteorological fields were used to drive an offline regional air-quality model. Three separate $10 \mathrm{yr}$ simulations of summer (June-July-August) air-quality were created. The first scenario examines the model's ability to reproduce the air-quality of the current climate, with a detailed statistical comparison against monitoring data collected across North America. The remaining two scenarios represent different possible sets of future conditions for the years 2041 to 2050. Both future experiments use the same set of RCMderived meteorology, following the SRES A2 scenario. The future scenarios differ in the anthropogenic air pollution precursor emissions assumed, with one scenario making use of current condition precursor emissions, and the other making use of one of the IPCC Representative Concentration Pathway emission scenarios (RCP 6) to scale the present-day emission fields to 2050 values. Results are presented for a domain covering most of the contiguous United States and Canada, noting here that few studies currently exist that examine the future impact of climate change on air quality in Canada. Tagaris et al. (2008) and Cheng et al. (2007b) represent the only future projections of which we are aware, and only cover southern Canada. The scenarios and differences between the scenarios are identified in Table 1 .

Differences between the first two scenarios $(\triangle C C$, see Table 1) provide guidance on the question "What are the impacts of climate change on air pollution, if air pollution precursor emissions are unchanged?" Differences between the first and third scenario ( $\triangle \mathrm{CE}$, see Table 1$)$ address the question, "How would the impact of climate change on air pollution be modified, in response to variations in anthropogenic air pollution precursor emissions?". In addition to
Table 1. Acronyms for model scenarios and calculated differences between scenarios.

\begin{tabular}{lll}
\hline Acronym & Description & Time Period \\
\hline Current & $\begin{array}{l}\text { Current climate, current } \\
\text { anthropogenic air pollu- } \\
\text { tion precursor emissions }\end{array}$ & 1997-2006 \\
\hline CC & $\begin{array}{l}\text { SRES A2 future climate, } \\
\text { current anthropogenic air } \\
\text { pollution precursor emis- } \\
\text { sions; “climate change } \\
\\
\text { only" scenario }\end{array}$ \\
\hline CE & $\begin{array}{l}\text { SRES A2 future climate, } \\
\text { RCP 6 emissions }\end{array}$ & 2041-2050 \\
\hline$\Delta$ CC & Change, CC - Current & $\begin{array}{l}\text { (2041 to 2050 aver- } \\
\text { age - 1997 to 2006 } \\
\text { average) }\end{array}$ \\
\hline$\Delta$ CE & Change, CE - Current & $\begin{array}{l}\text { (2041 to 2050 aver- } \\
\text { age - 1997 to 2006 } \\
\text { average) }\end{array}$ \\
\hline
\end{tabular}

scenario comparisons using various concentration metrics, we use our results to explore the impacts of air quality and climate change on human and ecosystem health, through the use of a multi-pollutant acute exposure metric, and deposition totals for acidifying pollutants and ozone.

We note that although comprehensive numerical models are the best tools currently available, these models are only approximations with uncertainties resulting from the grid resolution, choice of processes to represent in the model, and the manner in which these processes are represented (especially those involving the formation and behaviour of clouds and precipitation) (Hogrefe et al., 2004; Murphy et al., 2004; Stainforth et al., 2005). Different models handle processes occurring within the atmosphere in different ways, leading to a range of sensitivities to future climate change impacts (Hogrefe et al., 2004). These factors give rise to uncertainty in the projections presented below and argue for the use of multi-model ensembles of projections (US EPA, 2009).

\section{Methodology}

The modelling system used for this work has three components: the Canadian Coupled General Circulation Model (CGCM, v3.1), the Canadian Regional Climate Model (CRCM, v4.2.3), and A Unified Regional Air-quality Modelling System (AURAMS, v1.3.2). The global climate change projection was provided by the CGCM and dynamically downscaled to the higher resolution required for the regional CTM using the CRCM. High frequency output of all meteorological variables required by AURAMS was saved from the CRCM and AURAMS was subsequently run to 
calculate the chemistry and aerosol fields. The details of the setup of each model are given below.

\subsection{CGCM}

The global simulations were produced using the thirdgeneration of the Canadian Centre for Climate Modelling and Analysis Coupled General Circulation Model (Flato et al., 2000). The atmospheric components of the model are described in Scinocca et al. (2008) and, relative to the second generation model, contains notable improvements to the representation of land surface processes (Verseghy, 2000), a new orographic gravity wave drag parameterization (Scinocca and McFarlane, 2000) and a penetrative mass flux scheme for deep convection (Zhang and McFarlane, 1995). The atmospheric model is coupled to flux-adjusted version of the National Centre for Atmospheric Research Community Ocean Model (NCOM 1.3) (Gent et al., 1998). For the simulations used here the ocean model was run at an approximate resolution of 1.8 degrees with 29 vertical levels.

The future scenario used here followed the SRES A2 scenario and was one member of the ensemble submitted to the World Climate Research Programme's Third Coupled Model Intercomparison Project (CMIP3; Meehl et al., 2007).

\subsection{CRCM}

Detailed descriptions of the development of the Canadian Regional Climate model can be found in Caya and Laprise (1999), Laprise et al. (2003), Plummer et al. (2006), Sushama et al. (2010), and Mladjic et al. (2011). The CRCM operates on a uniform polar stereographic grid with a $45 \mathrm{~km}$ resolution true at $60^{\circ} \mathrm{N}$ (see Fig. 1 for the domain used here), and a Gal-Chen vertical coordinate with variable resolution is used. The CRCM vertical levels are staggered on terrain-following Gal-Chen coordinates (Gal-Chen and Sommerville, 1975) and increase in thickness from approximately $60 \mathrm{~m}$ at the surface to $3.5 \mathrm{~km}$ near the model lid at $29 \mathrm{~km}$. All vertical levels of the CRCM fall within the vertical domain of the driving data provided by the CGCM. Subgridscale physics in the fourth version of the CRCM makes use of the same package used in the CGCM3 (aside from the cumulus convection parameterization, which makes use of the Kain and Fritsch, 1990 formulation with modifications by Bechtold et al., 2001).

Lateral boundary conditions for the meteorological variables are interpolated from six-hourly output from the CGCM. One-way nesting using the method of Davies (1976) is applied over a nine-gridpoint wide buffer zone for horizontal winds, temperature and humidity. Within the interior of the CRCM large-scale, defined as having a wavelength of greater than $\sim 1400 \mathrm{~km}$, features in the horizontal winds and temperature are weakly nudged towards the CGCM fields. Nudging for the wind fields is only applied on model levels above $500 \mathrm{hPa}$ and for temperature above $50 \mathrm{hPa}$. More

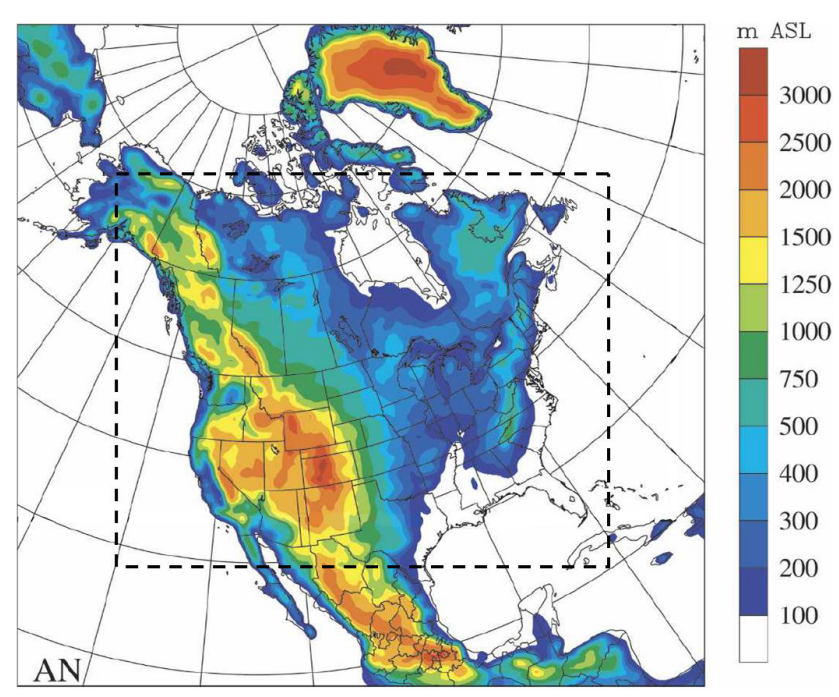

Fig. 1. CRCM and (within dashed line) AURAMS-CRCM grids, CRCM topography field shown.

details on the application of the nudging procedure can be found in Riette and Caya (2002).

In order to provide meteorological data to run AURAMS, extensive modifications were required to the CRCM's output procedures. Some of the fields from the CRCM are output as running averages or accumulated quantities, while AURAMS requires the entire state of the atmosphere to be provided at individual time steps. In addition, many of the fields required by AURAMS are not part of the CRCM's suite of standard outputs, in turn requiring additional coding to extract these variables from different parts of the CRCM code. These modifications did not affect the values of the model output - rather, the CRCM's output capacity was enhanced, in order to allow the additional fields and the high resolution time step of the output $(15 \mathrm{~min})$ to be available for use by AURAMS. This modified version of the CRCM was used to rerun 1 May through 30 August of the years 1997 through 2006, and 2041 through 2050, using restart files from a previously completed CRCM simulation covering the period 1959 through 2100. This procedure preserved the "spun-up" state of the soil-atmosphere system. Subsequent AURAMS simulations started on 15 May of each simulated year, with the 15-30 May period used as spin-up to allow AURAMS chemistry to reach a quasi-steady-state.

\subsection{AURAMS}

AURAMS is a comprehensive regional air-quality modelling system, consisting of a meteorological driver (usually the Global Environmental Multiscale model, GEM, Côté et al., 1998 but here the CRCM), an emissions processing system (Sparse Matrix Operating Kernal Emissions, SMOKE: Houyoux et al., 2000; CEP, 2003), the AURAMS meteorological pre-processor and the AURAMS chemical transport 
model (cf. Gong et al., 2006; Makar et al., 2010a). The AURAMS meteorological pre-processor reads in the input fields (meteorology, emissions, land use, etc.), carries out units conversion and performs any necessary spatial interpolation of the input fields to the AURAMS computational grid. Both the CRCM and AURAMS use the same projection (polar stereographic, true at $60^{\circ} \mathrm{N}$ ) and for the simulations presented here both models run at the same horizontal resolution $(45 \mathrm{~km})$ using co-located grid points - the only difference being that the AURAMS domain is a subset of the full CRCM domain. Therefore no horizontal interpolation of meteorological fields is required to pass information from the CRCM to AURAMS. While both models also use the same Gal-Chen vertical co-ordinate system, the location of the vertical levels of the two models is different and vertical interpolation is required to place fields on the AURAMS grid. AURAMS has 28 vertical levels, extending from the surface to approximately $18 \mathrm{~km}$ altitude and has been run with a $15 \mathrm{~min}$ timestep to match the frequency of output provided by the CRCM.

AURAMS operators and the numerical methods used for each are as follows (a one-step operator splitting is employed). Major point source emissions are calculated (plume rise buoyancy calculations according to Briggs, 1984, 1985; Turner, 1985 and Sharf et al., 1993), followed by semiLagrangian advection of all transported pollutants (Smolarkiewicz and Pudykiewicz, 1992). Vertical diffusion is carried out using a fully implicit Laasonen approach (Richtmyer, 1994), with area source emissions and gaseous deposition incorporated as boundary conditions on the diffusion equation. Gas-phase chemistry calculations follow (42 gas species, ADOM-II mechanism; Stockwell and Lurmann, 1989, numerically solved using the method of Young and Boris, 1977), with secondary organic aerosol condensable mass being estimated using the approach of Odum et al. (1996), with updated organic aerosol yields. This is followed by the Canadian Aerosol Module (Gong et al., 2003a, b) which resolves aerosol size and chemical speciation using 12 bins (sectional approach) for 9 species (sulphate, nitrate, ammonium, secondary organic aerosol, primary organic aerosol, elemental carbon, sea-salt, crustal material, and aerosol water). Processes treated by the aerosol module include particle microphysics (condensation of sulphate and secondary organic condensable mass, coagulation, nucleation of sulphate aerosols), aqueous-phase chemistry (ADOM aqueous phase mechanism, Venkatram et al., 1988; Fung et al., 1991; using solver of Young and Boris, 1977, for integration), wet deposition (precipitation production and flux from both resolved and sub-grid scales are included in the wet deposition calculation; Gong et al., 2006), inorganic heterogeneous chemistry of sulphate, nitrate and ammonium (HETV solver, Makar et al., 2003), sea-salt emissions (Gong et al., 2003a), and particle settling and deposition (Gong et al., 2003a; Zhang et al., 2001). Sub-grid-scale convective tracer mixing and transport is not included in AURAMS though these processes are resolved when AURAMS is used at high resolution. The gas-phase mechanism used in these simulations has been compared to a suite of other mechanism, with its predictions being close to the median for the ensemble of mechanisms tested (Kuhn et al., 1998). Photolysis rates were calculated using the data of Peterson (1976) and the radiative transfer model of Dave (1972), with crosssections and quantum yields from DeMore et al. (1988). Tabulated height and solar-zenith-angle dependent photolysis rates for $J_{\mathrm{NO}_{2}}$ and $J_{\mathrm{O}_{3} \rightarrow \mathrm{O}^{1} \mathrm{D}}$, as well as solar-zenith-angledependent scaling coefficients for the other photolysis reactions, are used within the model itself.

Biogenic emissions are calculated on-line within AURAMS (that is, the emissions are functions of temperature and photosynthetically active radiation, both of these parameters originating in the driving meteorology). The biogenic emission factors used in AURAMS were generated using version 3.09 of the Biogenic Emissions Inventory System algorithms (Pierce et al., 1998), with a land-use database originating in satellite-derived vegetation fields.

For the simulations described here, AURAMS was run in its native mode, with chemical concentration lateral and top boundary conditions corresponding to current conditions for all simulations. $\mathrm{CO}$ and $\mathrm{PM}_{2.5}$ boundary conditions are simplified profiles based on satellite observations, with seasonal and latitudinal variations. Short-lived chemical tracers have constant low concentration profiles on the boundaries. Ozone boundary conditions make use of monthly 3-D climatology with adjustments for model-predicted tropopause height (Makar et al., 2010b). Thus, meteorological downscaling was applied, but not chemical downscaling. The simulations thus provide information on the potential changes due to climate change within the model domain, but not how changing conditions outside of the model domain might influence the North American Air-Quality picture.

\section{Scenarios}

Three different air-quality scenarios were calculated with AURAMS at $45 \mathrm{~km}$ resolution using 10 consecutive summers (June, July and August) of CRCM meteorology derived for either current climate (1997-2006) or future climate (20412050) conditions. The scenarios included:

1. \{Current climate, current emissions; aka "Current", Table 1\}: 1997-2006 climate, with 2002 Canadian and US and 1999 Mexican anthropogenic air pollution precursor emissions.

2. \{Future climate, current emissions; aka "CC", Table 1\}: 2041-2050 SRES A2 climate, with 2002/1999 anthropogenic air pollution precursor emissions. 
Table 2. Projected $\mathrm{O}_{3}$ and Aerosol precursor emissions for 2020 and 2050 for the OECD group of countries from IPCC emission scenarios. SRES data is taken from IPCC (2000) and RCP data is taken from RCP Database (2012).

\begin{tabular}{|c|c|c|c|c|c|c|}
\hline \multicolumn{2}{|l|}{ Year } & \multirow{2}{*}{$\begin{array}{l}2000 \\
\text { SRES-A2 }\end{array}$} & \multicolumn{2}{|c|}{ A2 } & \multicolumn{2}{|c|}{ RCP6 } \\
\hline Emitted Species & Units & & 2020 & 2050 & 2020 & 2050 \\
\hline $\mathrm{SO}_{\mathrm{x}}$ total & $\mathrm{Tg}_{-} \mathrm{S} \mathrm{yr}^{-1}$ & 17 & 8.7 & 9.8 & 11 & 4.6 \\
\hline $\mathrm{CO}$ & $\mathrm{Tg}-\mathrm{CO} \mathrm{yr}^{-1}$ & 161 & 175 & 141 & 153 & 99 \\
\hline NMVOCs & $\operatorname{Tg}_{\mathrm{yr}}{ }^{-1}$ & 36 & 44 & 42 & 33 & 25 \\
\hline $\mathrm{NO}_{\mathrm{x}}$ & $\mathrm{Tg}-\mathrm{N} \mathrm{yr}{ }^{-1}$ & 12 & 16 & 16 & 9.0 & 4.5 \\
\hline
\end{tabular}

3. $\{$ Future climate, RCP 6 emissions; aka "CE", Table 1\}: 2041-2050 SRES A2 climate, with emissions derived following Representative Concentration Pathway 6.0 scaling information.

The last of these scenarios makes use of the IPCC's Representative Concentration Pathway 6.0 (RCP 6; Fujino et al., 2006; Hijioka et al., 2008) to estimate future precursor emissions. RCP 6 is a moderate-range stabilization scenario where the total radiative forcing is stabilized after 2100. The RCP scenarios include a detailed development of the smog-precursor links to green-house gas emitting activities, and how changing these activities would also change anthropogenic smog precursor emissions. The RCP scenarios differ from the earlier $\mathrm{A} 2$ and $\mathrm{A} 1 \mathrm{~B}$ scenarios in that they include sector-specific control technologies in the estimation of emissions changes. The RCP 6 emissions scenario includes decadal changes for 108 emitting activities, for $\mathrm{CO}_{2}, \mathrm{CH}_{4}, \mathrm{~N}_{2} \mathrm{O}, \mathrm{SO}_{\mathrm{x}}, \mathrm{CO}$, non-methane volatile organic compounds, $\mathrm{SO}_{2}, \mathrm{NO}_{\mathrm{x}}$, and $\mathrm{NH}_{3}$. In contrast, the standard US, Canadian and Mexican databases for North American air-pollution forecasting, and their 2020 projections, contain over ten thousand emitting sources and over a thousand emissions splitting profiles by activity type, as well as GISbased spatial allocation fields and temporal splitting fields for hourly level emissions. This level of detail is required for the regional model emissions, yet was not available in the IPCC data with RCP 6 . In order to make the connection between the two databases, the 108 RCP 6 emitting activities were first mapped to the more detailed North American inventory sources. The ratio of the RCP 6 values for 2020 and 2050 for the OECD group of countries were used to scale the detailed inventory projections for 2020 to the year 2050. The detailed inventory projections for 2020 were created assuming only currently legislated controls would be in place by that year. The resulting scaling factors were applied in the SMOKE emissions processing system, used to create all smog precursor emissions datasets used in the AURAMS-CRCM simulations. The resulting emission fields for 2050 are referred to below as the RCP 6 emissions.

The use of current anthropogenic precursor emissions with an SRES A2 future climate (or RCP 6 future anthropogenic precursor emissions in conjunction with an SRES A2 future climate) raises the issue of inconsistency between the climate and air-quality emissions. To be very specific, the future scenarios employed here make use of A2 greenhouse gas emissions, and present-day (or RCP 6) emissions of other anthropogenic pollutants. Both future scenarios thus diverge from IPCC projections. However, the use of current anthropogenic precursor emissions in conjunction with future climate is the only logical means to determine the impact of climate change alone on air-quality for the A2 future climate. This approach has been used extensively in the literature in the past. By the same token, making use of RCP 6 smog precursor emissions and A2 future climate allow the combined effects of emission changes and climate change to be assessed. The RCP 6 smog precursor emissions were chosen due to their level of detail in comparison to the earlier SRES projections (making them ideally suited to detailed scaling of emissions with the SMOKE emissions processing system). We also chose to scale future emissions following RCP 6 because this projection reflects the current view that precursor emissions in developed countries will continue to decrease in the future. We note that all of the RCPs show continued decreases in precursor emissions for developed countries (OECD90) throughout the 21st century, despite large differences in GHG emissions. As can been seen below in Table 2, the use of the original SRES A2 projections to derive emission changes from 2020 to 2050 would have resulted in very different future emissions. The A2 climate scenario was chosen out of necessity (GCM and RCM runs being available for this scenario and not for A1B or RCP 6). However, global radiative forcing and mean temperatures from multi-model ensembles show relatively little spread in their predictions by 2050 for the different scenarios, with the largest changes occurring after this time. Nevertheless, our "RCP 6" scenario here should thus be taken as an indication of how RCP 6 smog precursor emissions would impact air-quality under an A2 climate, but not how RCP 6 greenhouse gas emissions would affect climate.

The current and RCP 6 total emissions per day are compared to each other for four different anthropogenic source categories in Fig. 2. Figure 2a shows the emissions of the volatile organic compounds (VOCs) resolved in the gasphase mechanism in AURAMS (note that the emissions of C4+ Alkanes have been reduced by a factor of 10 to allow 

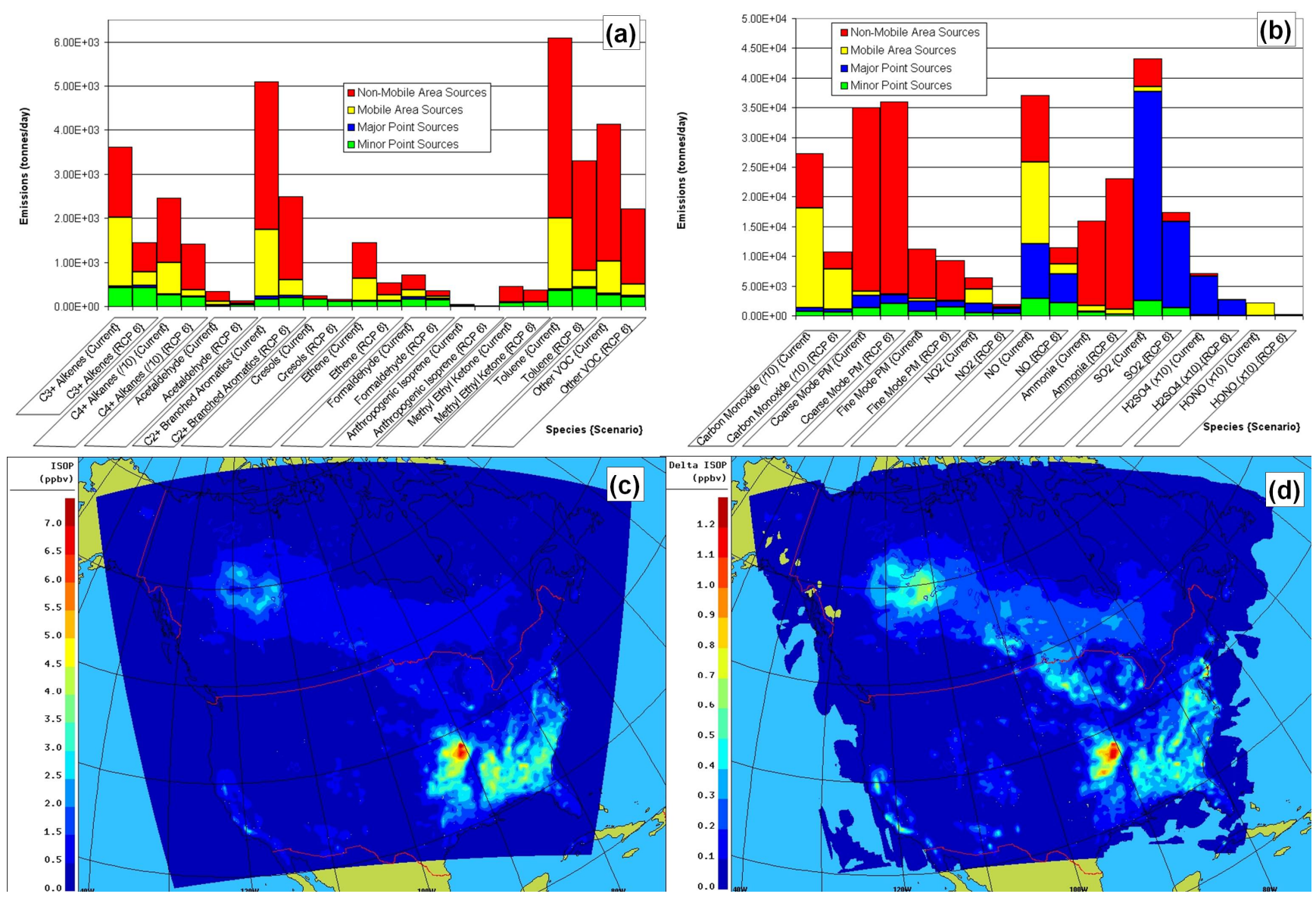

Fig. 2. Comparison of current and RCP 6 emissions for (a) the suite of emitted anthropogenic VOCs in the model mechanism, and (b) other emitted species. Note that some species' emitted mass has been scaled to allow plotting on the same vertical axis. "/10" in the species' name means the emitted mass has been reduced by a factor of ten, " $\times 10$ " means the emitted mass has been increased by a factor of 10 . Changes associated with biogenic emissions can be seen in through comparing the average summer isoprene concentration under current climate conditions (c), to the change in average summer isoprene in the future climate (d).

all emissions to be plotted on the same figure). Significant declines in all VOCs take place in the RCP 6 scenario, with most of the decreases resulting from decreases in emissions from mobile (yellow) and non-mobile (red) area sources. Figure $2 b$ shows the changes in emissions associated with other species in the model. Carbon monoxide decreases by over a factor of two, driven by changes in the same sources as for the VOCs. Emissions of coarse mode particulate matter increase, with decreases from the area sources being offset by increases in the minor point sources. The cause of the coarse mode PM emissions increases is two-fold and relates to the scaling factor procedure used here: the projections from 2005 to 2020 assume an increase in coarse mode PM associated with several sources of coarse mode PM from non-mobile area sources and minor point sources, while the RCP 6 ratios of primary coarse mode PM assume no change between 2020 and 2050. The net result is thus a slight increase in the primary coarse mode PM emissions between 2005 and our 2050 projection. Emissions of fine mode partic- ulate matter decreases slightly, while emissions of $\mathrm{NO}, \mathrm{NO}_{2}$, $\mathrm{SO} 2, \mathrm{H}_{2} \mathrm{SO}_{4}$ and $\mathrm{HONO}$ have decreased by over a factor of two (HONO emissions are calculated as a percentage of mobile $\mathrm{NO}_{\mathrm{x}}$ emissions by the SMOKE emissions processing system, hence the RCP $6 \mathrm{NO}_{\mathrm{x}}$ emissions changes result in $\mathrm{HONO}$ emissions changes). Ammonia emissions increase in the RCP 6 scenario, mostly due to assumed increases in non-mobile area sources, which are dominated by agricultural emissions.

Biogenic emissions for all cases are calculated from BEIS3.09 assuming no change in the distribution of vegetation between present and future conditions. The rate of biogenic emissions depends only on temperature and light levels, with no accounting for possible effects on changes in emission rates from water stress or changes in the concentration of $\mathrm{CO}_{2}$. The average summer concentration of (mostly) biogenically produced isoprene are compared for the current and $\mathrm{CE}$ scenarios in Fig. $2 \mathrm{c}$ and d, the latter showing the difference in isoprene between current and future climates. 
Table 3. AURAMS-CRCM Performance Statistics for "Current" scenario: ozone.

\begin{tabular}{|c|c|c|c|c|c|c|c|c|}
\hline Metric & $R^{2}$ & $R$ & Slope & $\begin{array}{c}\text { Intercept } \\
\text { Bias }\end{array}$ & $\begin{array}{c}\text { Mean Square } \\
\text { Error }\end{array}$ & $\begin{array}{l}\text { Root Mean } \\
\text { Mean Bias }\end{array}$ & $\begin{array}{l}\text { Normalized } \\
\text { Mean Error }\end{array}$ & Normalized \\
\hline Minimum & 0.23 & 0.48 & 0.60 & 21.8 & 12.5 & 15.4 & 0.54 & 0.56 \\
\hline Maximum & 0.37 & 0.61 & 0.98 & 12.2 & 10.2 & 22.9 & 0.12 & 0.19 \\
\hline Mean & 0.38 & 0.62 & 0.88 & 17.6 & 11.2 & 16.5 & 0.22 & 0.27 \\
\hline $\begin{array}{l}\text { 4th Highest } \\
\text { Maximum }\end{array}$ & 0.37 & 0.61 & 0.96 & 14.2 & 11.4 & 21.2 & 0.15 & 0.22 \\
\hline 10th Percentile & 0.34 & 0.58 & 0.75 & 19.5 & 11.1 & 14.9 & 0.33 & 0.36 \\
\hline 90th Percentile & 0.36 & 0.60 & 0.91 & 17.6 & 11.2 & 19.6 & 0.16 & 0.23 \\
\hline 98th Percentile & 0.36 & 0.60 & 1.00 & 11.9 & 11.9 & 23.5 & 0.14 & 0.21 \\
\hline $\begin{array}{l}\text { Days exceeding } \\
\text { Canada-Wide } \\
\text { Standard }\end{array}$ & 0.25 & 0.50 & 0.93 & 20.4 & 19.0 & 31.1 & 1.00 & 1.31 \\
\hline $\begin{array}{l}\text { Days exceeding } \\
\text { National Ambient } \\
\text { Air Quality Standard }\end{array}$ & 0.16 & 0.39 & 0.92 & 14.8 & 14.1 & 25.2 & 1.63 & 2.09 \\
\hline Standard Deviation & 0.31 & 0.56 & 0.83 & 2.3 & 0.0035 & 4.23 & 0.00026 & 0.23 \\
\hline
\end{tabular}

Isoprene concentrations are suggested to increase over much of the continent. However, it should be noted that with increased $\mathrm{CO}_{2}$ concentrations, the size of the opening of plant stomata required for $\mathrm{CO}_{2}$ uptake may be smaller than under current environments. This may potentially reduce biogenic emissions fluxes under future climate conditions below those described here.

Wildfire emissions have not been included in either current emissions or future projections. Wildfires may have a very substantial impact on air-quality over large regions. The magnitude of changes in wildfire emissions due to climate change is complex, due to uncertainties within the emissions algorithms themselves, as well as in projecting forest cover and fire-inducing conditions in the future. Nevertheless, the absence of wildfire emissions is a potential confounding factor on the results presented here.

\section{Model performance}

In order to evaluate the model performance, observations carried out over North America for the current climate period (1997-2006) were collected from ozone and $\mathrm{PM}_{2.5}$ observation stations across the continent. For a particular station, data for the study period was deemed complete when data was available for 7 or more years, and each of the reporting years had data for $75 \%$ or more of the days in June, July and August. The data at each station were used to determine the station summer average for the average daily maximum $8 \mathrm{~h}$ ozone and the $24 \mathrm{~h}$ average $\mathrm{PM}_{2.5}$. Summer aver- ages for the maximum, minimum, 4th highest maximum, various percentiles, Canada-wide Standard (CWS) and US National Ambient Air-Quality Standard (NAAQS) values were also calculated for each year. The last two metrics were calculated as the number of days exceeding the standard (hence the correlation coefficients were for the number of days of exceedence between model and observations). The summer averages were then combined across years, to create climatological ten-year summer averages, and then compared to model-derived values. The resulting evaluative statistics are shown in Tables 3 and 4 . Scatterplots for the $10 \mathrm{yr}$ average of the mean summer daily maximum $8 \mathrm{~h}$ average ozone and the $10 \mathrm{yr}$ average of the daily average $\mathrm{PM}_{2.5}$ are shown in Fig. 3 . The model has a 10 to $11 \mathrm{ppbv}$ positive bias for most ozone statistics, slopes close to unity for most statistics (except for minimum ozone), and correlation coefficients $(R)$ values ranging from 0.39 for NAAQS to 0.62 for mean ozone. The ozone statistics (Table 3 ) are similar to those achieved for AURAMS simulations using its standard meteorological driver (the Canadian Weather Forecast model: Global Environmental Multiscale - GEM). Simulations at 42, 15 and $2.5 \mathrm{~km}$ grid spacing (Makar et al., 2010a) suggest that much of the positive bias in these model simulations is the result of insufficient $\mathrm{NO}_{\mathrm{x}}$ titration at the relatively low resolution of $42 \mathrm{~km}$, and would be eliminated with further downscaling to higher grid resolutions than those attempted here. The $\mathrm{PM}_{2.5}$ statistics (Table 4) are similar to those achieved by this version of AURAMS driven by GEM in terms of correlation coefficient, with the important exceptions of the mean bias (which is more negative than achieved with GEM), and the 

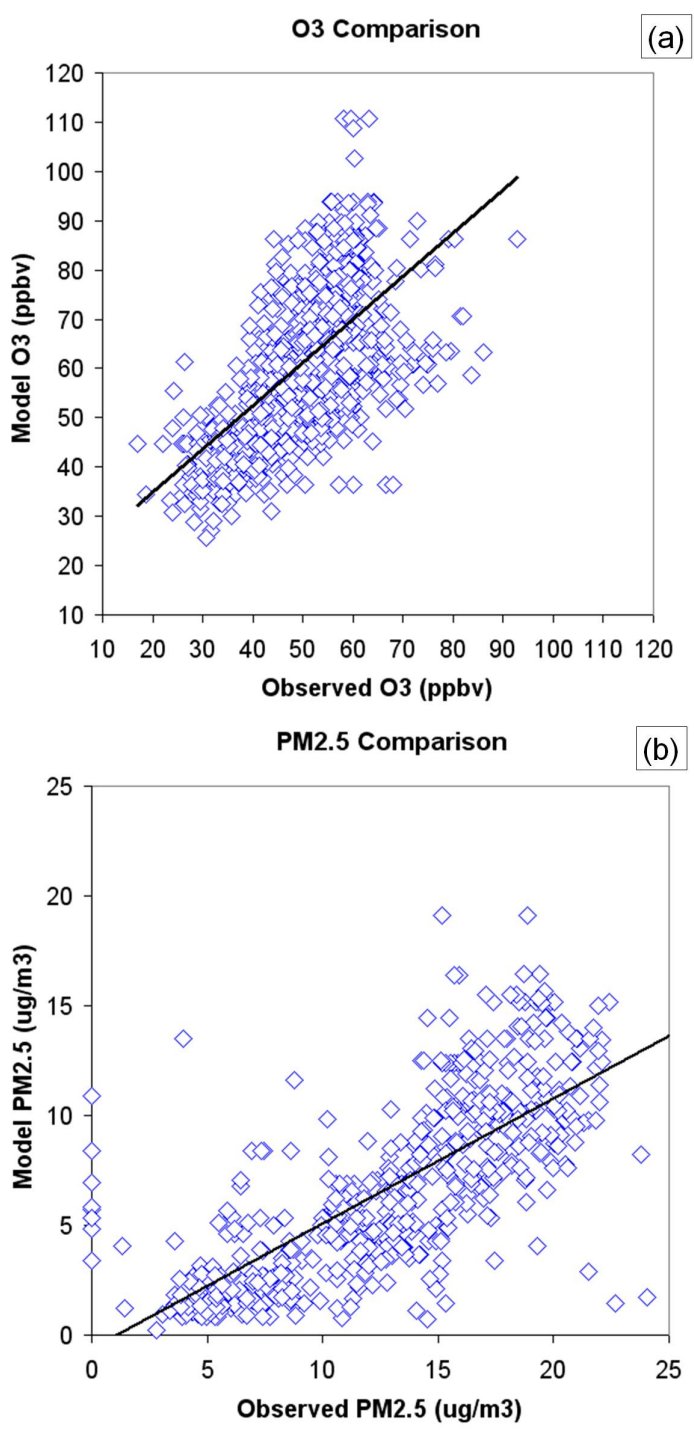

Fig. 3. Scatterplots of "Current" scenario comparisons to observations. (a) Summer average maximum daily $8 \mathrm{~h}$ average $\mathrm{O}_{3}$ (ppbv), 915 stations. (b) Summer average daily average $\mathrm{PM}_{2.5}\left(\mu \mathrm{g} \mathrm{m}^{-3}\right)$, 565 stations. Statistical measures are given in Tables 4 and 5.

correlation coefficients for CWS and NAAQS which are relatively low. The relatively high negative bias in the CRCMdriven AURAMS results is likely due to two factors: the cloud physics package for this version of the CRCM lacks a parameterization for the evaporation of falling rain, and the surface temperatures of the CRCM over the western mountains and the boreal forest regions of the continent have negative biases. The former process has been shown to be a significant source of particle sulphate $\left(\mathrm{SO}_{2}\right.$ taken up by clouds is converted to sulphuric acid and is released as sulphate particles when rain evaporates en route to the ground). The latter reduces the rate of biogenic emissions, hence reducing the rate of secondary organic aerosol formation from the oxidation these hydrocarbons released by vegetation.

\section{Model predictions: meteorological changes: current climate versus future climate}

The reader is referred to Plummer et al. (2006) for an indepth analysis and evaluation of the RCM's meteorological predictions.

Three examples of the expected changes in meteorology are given below: lowest model layer temperatures, relative humidity and downwelling solar radiation at the surface. Ten year averages of the each summer's average and 98th percentile values for these fields are given in Figs. 4 to 6 .

Figure 4 shows that the average summer temperature is expected to increase, with the extent of the increase varying greatly in space, and maximum values of around $2.2^{\circ} \mathrm{C}$. The largest increases occur in the centre of the continent. Northwestern USA and south-western Canada have summer average temperature increases between 1.0 and $1.7^{\circ} \mathrm{C}$ near the Pacific, with temperature increases rising as high as $1.9^{\circ} \mathrm{C}$ with increasing distance inland. The pattern of changes in summer season average surface temperature are broadly similar to those shown in Plummer et al. (2006) for an earlier version of the CRCM, though the magnitude of the increases found here are slightly smaller. The second row of contour maps in Fig. 4 shows the summer average 98th percentile temperature, and its (future-current) difference. The 98th percentile temperatures are the high temperature extremes; the lower half of the figure thus shows the hottest days of the summer on the left, and the change in the temperatures of the hottest days on the right. The lower right figure is significant in that the change in temperatures for the hottest summer days have increased more than the average (compare upper and lower right panels of Fig. 4, which have different temperature scales). The pattern of the increase in extreme temperatures is very spatially inhomogeneous, with the greatest increase in local extreme temperatures occurring in the Canadian provinces of Ontario and Quebec, followed by parts of the north-eastern USA and northern Canada. For example the increase in the average mean temperature for Toronto is 1.7 to $1.9^{\circ} \mathrm{C}$, while the corresponding increase in the average 98th percentile temperature is 2.6 to $3.0^{\circ} \mathrm{C}$. The temperature maps thus show an increase in average temperature, and an increase in the magnitude of extreme heat conditions, for most of the continent.

Figure 5 shows the mean summer average and 98th percentile specific humidity in the current climate simulations, and their change between future and current climates. The specific humidity is a measure of the water content of the atmosphere, and influences atmospheric chemistry through different mechanisms (e.g. setting the background level of the $\mathrm{OH}$ radical, influencing the equilibria of inorganic particle chemistry, etc.). Specific humidity increases in both the mean and the 98th percentile, with the latter increases the largest in the Mississippi basin, southern Florida, and the Red River basin. Similar to temperature, specific humidity increases at the 98th percentile are in general higher than the 
Table 4. AURAMS-CRCM Performance Statistics for "Current" scenario: $\mathrm{PM}_{2.5}$.

\begin{tabular}{|c|c|c|c|c|c|c|c|c|}
\hline Metric & $R^{2}$ & $R$ & Slope & Intercept & $\begin{array}{r}\text { Mean } \\
\text { Bias }\end{array}$ & $\begin{array}{r}\text { Root Mean } \\
\text { Square Error }\end{array}$ & $\begin{array}{l}\text { Normalized } \\
\text { Mean Bias }\end{array}$ & $\begin{array}{l}\text { Normalized } \\
\text { Mean Error }\end{array}$ \\
\hline Minimum & 0.47 & 0.68 & 0.39 & -0.01 & -2.4 & 2.8 & -0.62 & 0.63 \\
\hline Maximum & 0.27 & 0.52 & 0.34 & 7.13 & -13.8 & 18.9 & -0.43 & 0.46 \\
\hline Mean & 0.55 & 0.74 & 0.57 & -0.63 & -6.3 & 7.2 & -0.48 & 0.50 \\
\hline $\begin{array}{l}\text { 4th Highest } \\
\text { Maximum }\end{array}$ & 0.38 & 0.62 & 0.51 & 3.13 & -7.5 & 10.9 & -0.35 & 0.40 \\
\hline 10th Percentile & 0.52 & 0.72 & 0.53 & -0.22 & -2.9 & 3.4 & -0.50 & 0.52 \\
\hline 90th Percentile & 0.53 & 0.73 & 0.55 & -0.67 & -11.0 & 12.7 & -0.48 & 0.51 \\
\hline 98th Percentile & 0.39 & 0.63 & 0.44 & 2.78 & -14.5 & 17.6 & -0.47 & 0.49 \\
\hline $\begin{array}{l}\text { Days exceeding } \\
\text { Canada-Wide } \\
\text { Standard }\end{array}$ & 0.04 & 0.20 & 0.09 & 0.21 & -1.6 & 3.2 & -0.81 & 0.90 \\
\hline $\begin{array}{l}\text { Days exceeding } \\
\text { National Ambient } \\
\text { Air Quality Standard }\end{array}$ & 0.02 & 0.13 & 0.04 & 0.09 & -0.9 & 1.9 & -0.87 & 0.94 \\
\hline Standard Deviation & 0.42 & 0.65 & 0.46 & 0.48 & -3.1 & 3.8 & -0.47 & 0.50 \\
\hline
\end{tabular}

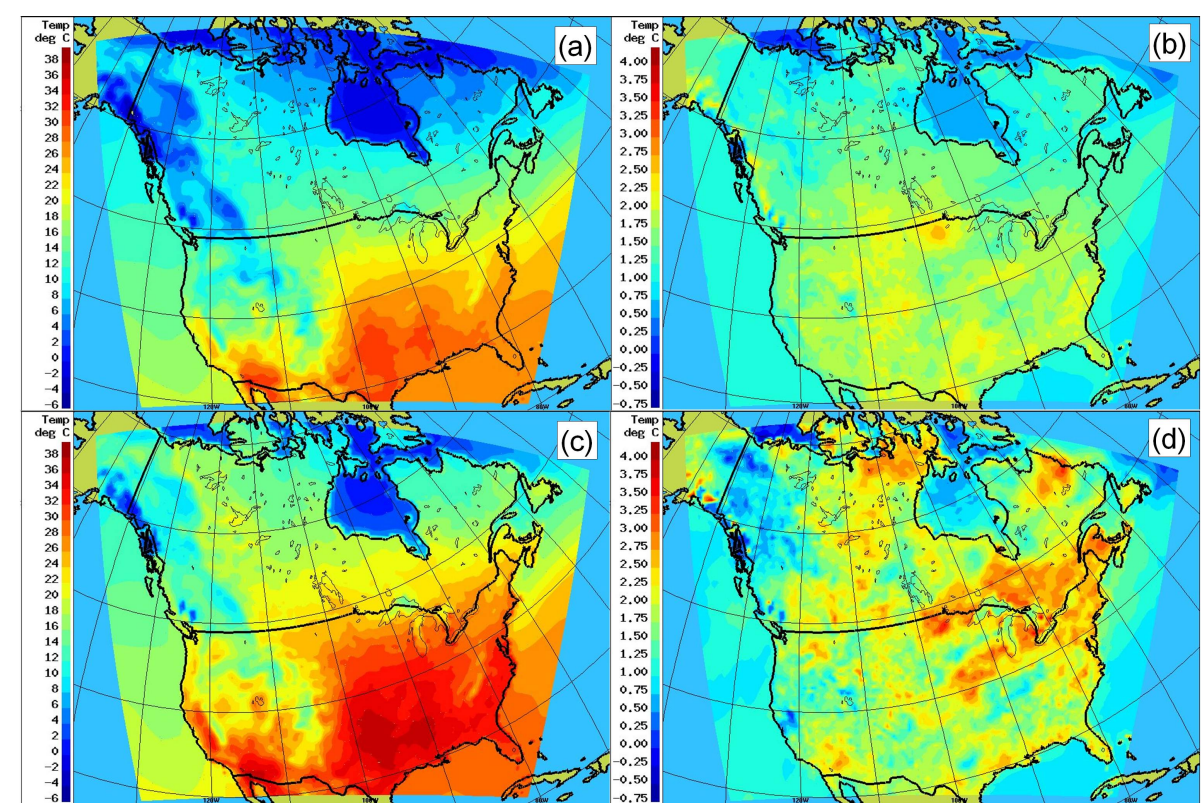

Fig. 4. (a) Ten year average current climate (1997-2006) lowest model layer mean summer temperature. (b) Change in temperature (future climate-current climate). (c) Ten year average current climate (1997-2006) lowest model layer 98th percentile summer temperature. (d) Change in average 98th percentile temperature (future climate-current climate).

increases in the average, indicating an increase in the magnitude of extreme humidity events across the continent, in a spatially inhomogeneous pattern.

Figure 6 shows the mean summer average and 98th percentile of the average summer incoming solar radiation at the surface. The incoming solar radiation at the surface is an indicator of cloudiness, of surface photolysis rates, and also affects the emission rate of biogenic isoprene. The climate response is spatially inhomogeneous: average incoming solar radiation increases over much of eastern and central North America (Fig. 6b, orange to red regions), particularly along the US south-east coastline and the region from the 


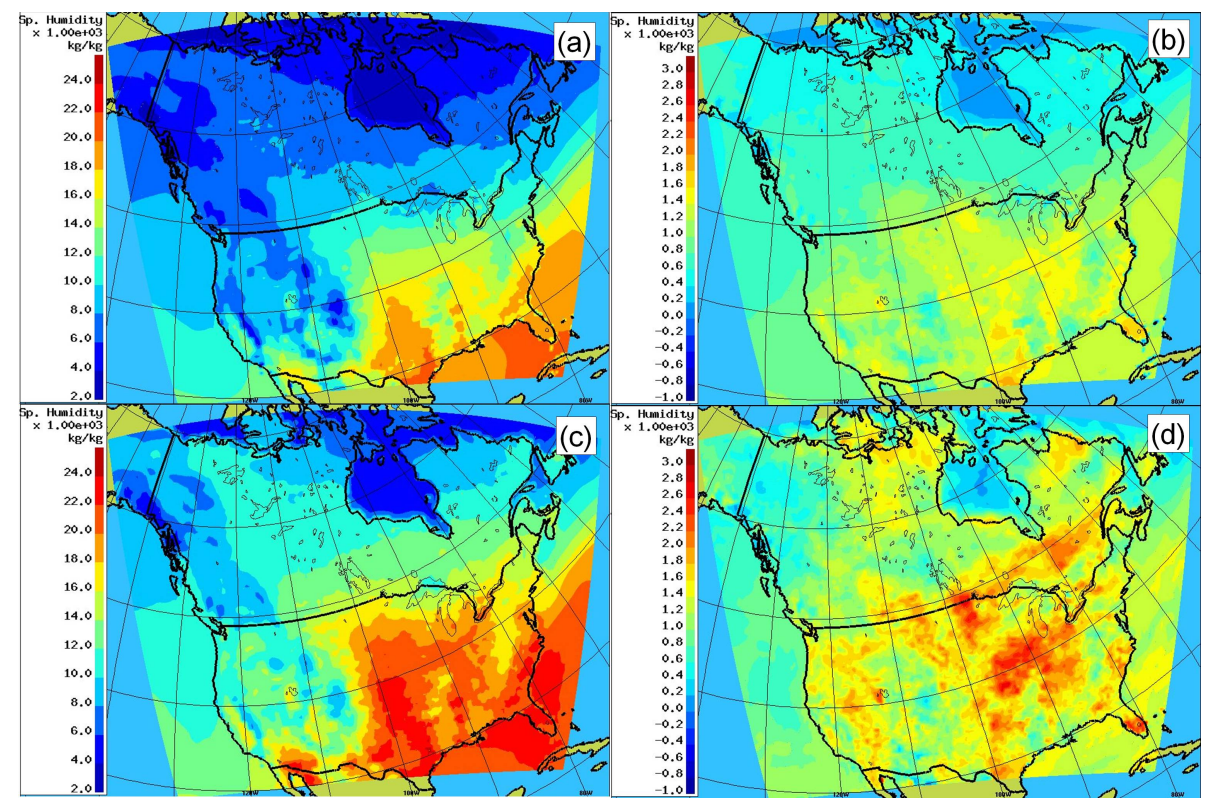

Fig. 5. (a) Ten year average current climate (1997-2006) lowest model layer summer specific humidity. (b) Change in specific humidity (future climate-current climate). (c) Ten year average current climate (1997-2006) lowest model layer 98th percentile summer specific humidity. (d) Change in average 98th percentile specific (future climate-current climate).

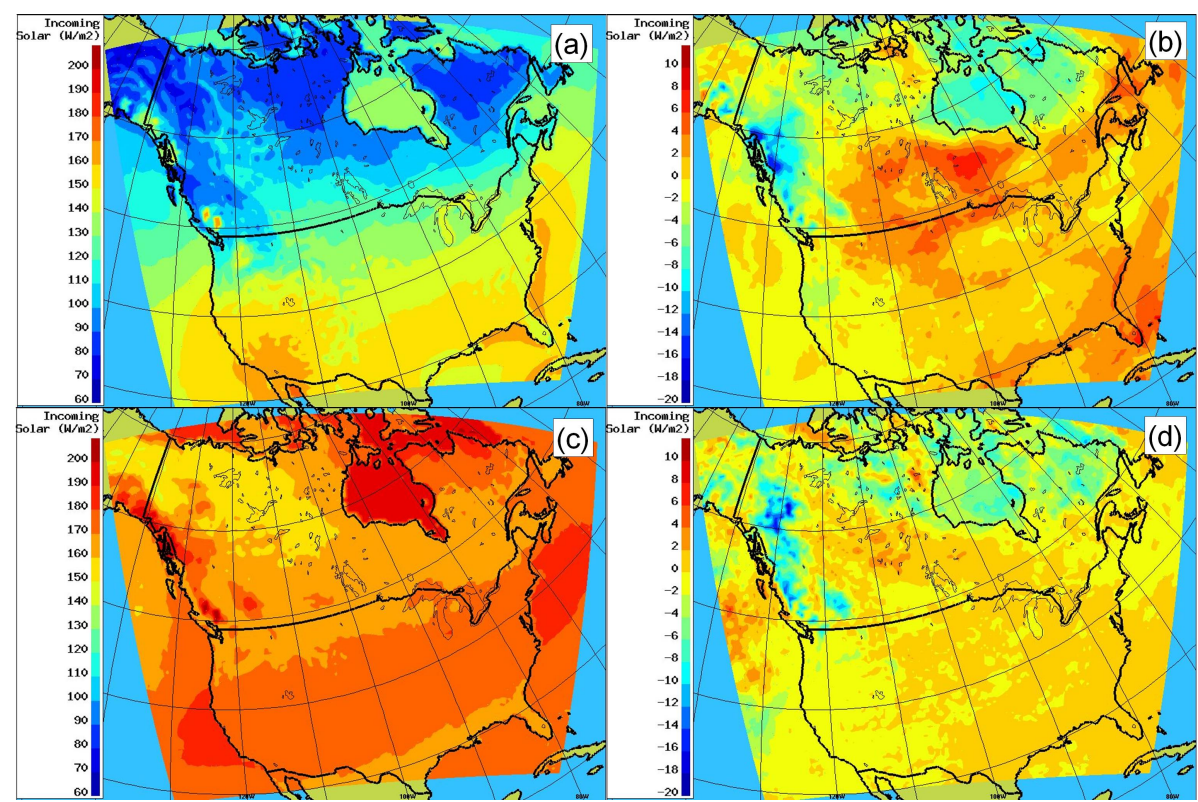

Fig. 6. (a) Ten year average current climate (1997-2006) average summer incoming solar radiation at the surface $\left(\mathrm{W} \mathrm{m} \mathrm{m}^{-2}\right)$. (b) Change in average summer incoming solar radiation (future climate-current climate). (c) Ten year average current climate (1997-2006) 98th percentile summer incoming solar radiation (d) change in average 98th percentile incoming solar radiation (future climate-current climate).

Prairie provinces of Canada eastwards to the Atlantic). Solar radiation is projected to decrease in parts of the western mountain ranges, with particularly large decreases over western Canada, and a broad band of decreases across northern Canada (yellow to blue colours). The changes for the 98th percentile values (Fig. 6d) are shown for consistency with the earlier figures but are of limited use as the 98th percentile likely results from clear sky values for much of the model domain. Changes in the 98th percentile are thus near zero over most of the model domain. The main tendency is thus an increase in average incoming solar radiation at the surface over much of North America, particularly the heavily 


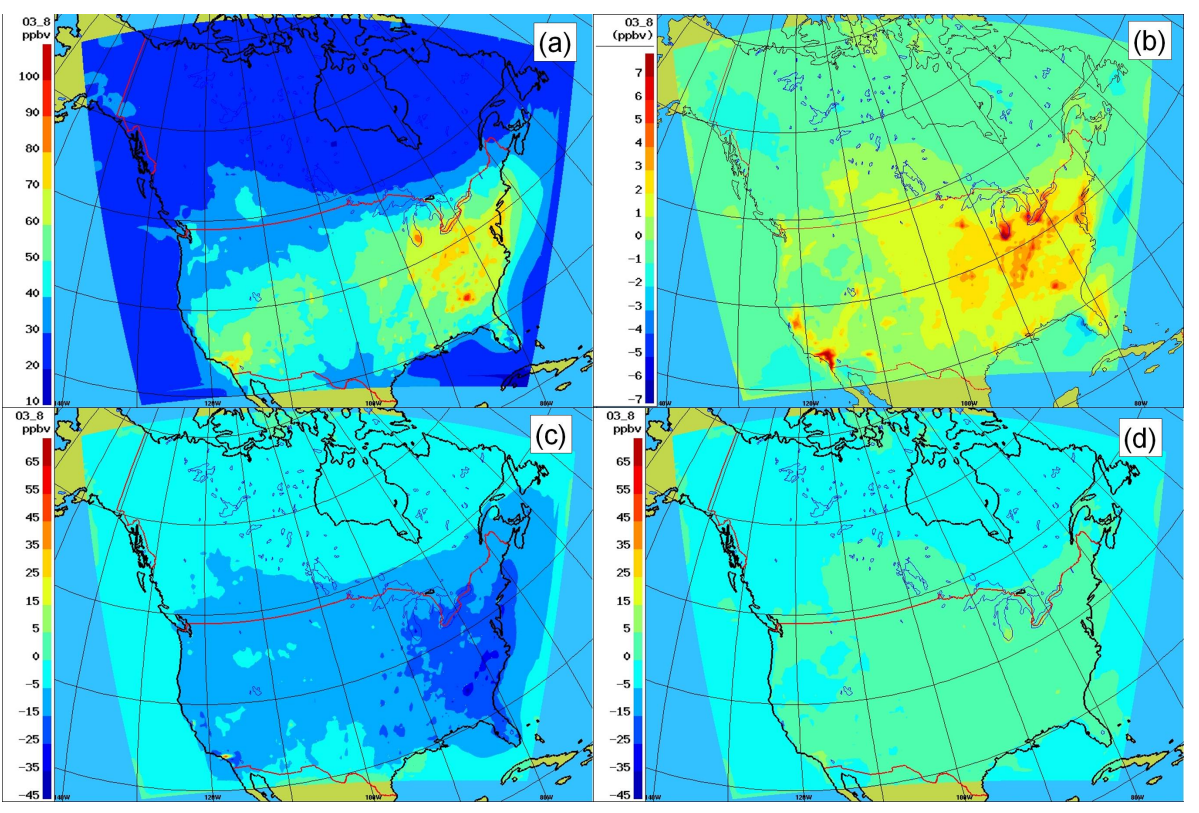

Fig. 7. (a) Ten year average "Current" lowest model layer mean summer daily maximum $8 \mathrm{~h}$ average $\mathrm{O}_{3}$. (b) $\Delta \mathrm{CC}$. (c) $\Delta \mathrm{CE}$. (d) $\Delta \mathrm{CC}$, but with the colour scale of $\triangle \mathrm{CE}$, for comparison purposes.

industrialized eastern United States and adjoining regions of southern Canada, suggesting that increased photochemical activity may occur over these regions.

These results indicate that the effect of climate change on air-quality are likely to be highly variable; in general, mean temperatures and humidity levels increase, and the magnitude of extreme events increases (the most hot and humid days become more hot and humid), but these changes are highly dependent on location. Some areas are shown to have less cloud cover on average, though again this is spatially heterogeneous. The climate model alone is thus insufficient to predict possible air-quality outcomes; the analysis now turns to the differences predicted by AURAMS for the different scenarios.

\section{Model predictions: air-quality changes}

The ten year averages of the mean summer daily maximum $8 \mathrm{~h}$ ozone concentrations across North American for the three scenarios are shown in Fig. 7. The AURAMS results are presented as sets of four images; the average concentration fields for the "Current" scenario (Fig. 7a) are followed by differences; $\triangle \mathrm{CC}$ (Fig. 7b), and $\Delta \mathrm{CE}$ (Fig. 7c), while the final image shows the $\Delta \mathrm{CC}$ field with the same colour scale as $\Delta \mathrm{CE}$, allowing a comparison of the magnitude of the changes resulting from the two future emissions scenarios. The most significant features of the future scenarios are the difference in the expected sign and magnitude of the change in ozone concentrations. Figure $7 b$ shows that $\mathrm{O}_{3}$ concentrations are largely expected to increase with climate change (maximum increases on the order of 9 to $10 \mathrm{ppbv})$. The largest increases occur in the region around Los Angeles, Chicago, Detroit and other urban regions in the US. In contrast, Fig. 7c shows that the RCP 6 emissions under the SRES A2 climate result in very large decreases in $\mathrm{O}_{3}$ (sometimes greater than $35 \mathrm{ppbv}$ ), extending across the eastern US. Decreases of 5 to $15 \mathrm{ppbv}$ occur much of the rest of Canada and the US under the RCP 6 scenario. Almost the entire domain in Fig. 7c experiences ozone decreases, the one exception being Greater Los Angeles, where decreases in $\mathrm{NO}_{\mathrm{x}}$ emissions in the downtown core have lead to reduced ozone titration, hence significant increases in ozone in that location. Comparison of Fig. 7c and $d$ shows that the increases in ozone expected via climate change (Fig. 7c) are much smaller in magnitude than the decreases in ozone that could be achieved via the significant precursor emissions reductions associated with the RCP 6 emissions scenario (Fig. 7d).

The equivalent analysis for the ten year average mean summer daily average $\mathrm{PM}_{2.5}$ concentrations across North America is shown in Fig. 8. The projected effects of climate change alone $(\triangle C C)$ is shown in Fig. 8b. The $\mathrm{PM}_{2.5}$ mass increases by between 0.5 and $1.0 \mu \mathrm{g} \mathrm{m}^{-3}$ over much of the inland eastern United States, while lower magnitude increases $\left(>0.2 \mu \mathrm{g} \mathrm{m}^{-3}\right)$ occur over much of North America. Large increases $\left(>1.0 \mu \mathrm{g} \mathrm{m}^{-3}\right)$ are also seen over Hudson's Bay and are driven by increases in natural sea-salt aerosol emissions, with the reduction of ice cover and increased winds in that region. Climate change alone will thus cause particulate matter to increase in these regions, even if anthropogenic precursor emissions remain constant at their current values. The CE scenario (Fig. 8c) has large reductions in $\mathrm{PM}_{2.5}$ over much of 


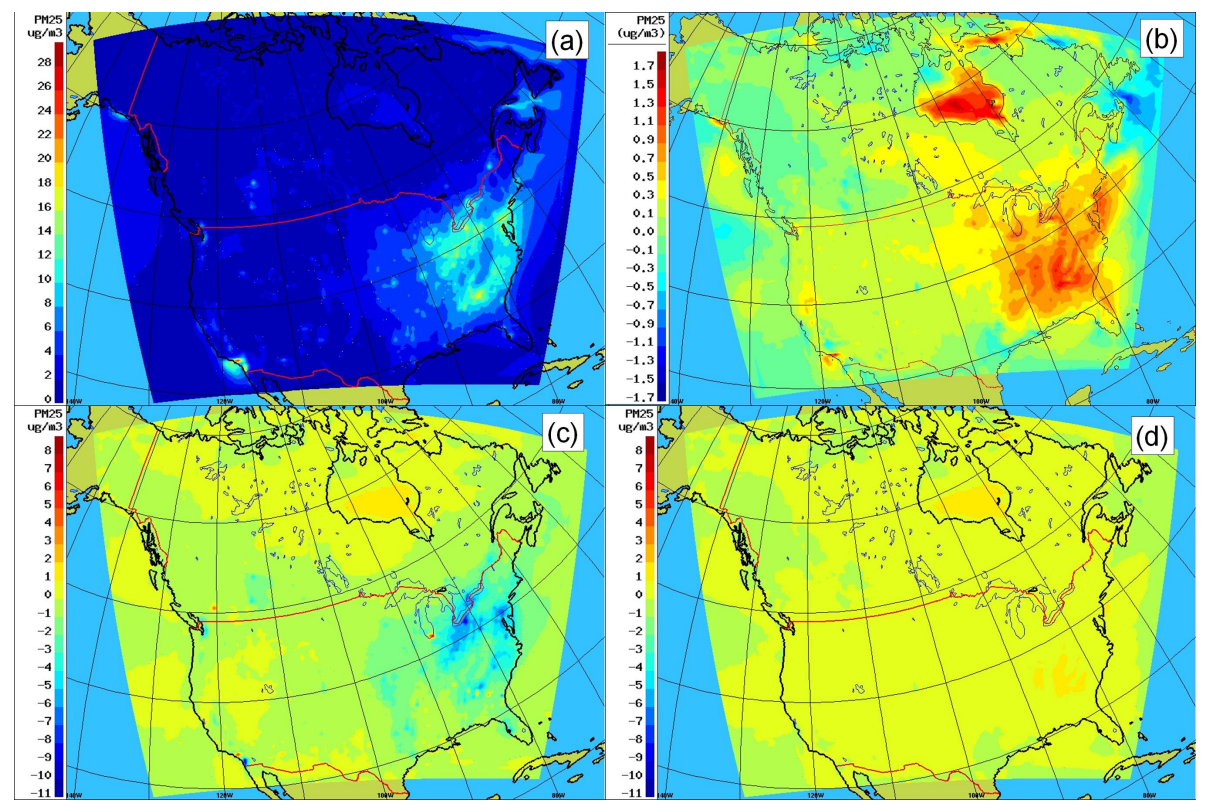

Fig. 8. As in Fig. 7, daily average $\mathrm{PM}_{2.5}$.

the eastern USA and the Ontario to Quebec corridor (reductions of up to $10 \mu \mathrm{g} \mathrm{m}^{-3}$ in some regions, and larger regional decreases of more than $3 \mu \mathrm{g} \mathrm{m}^{-3}$ ). Some very local areas see increases in $\mathrm{PM}_{2.5}$ with RCP 6, Chicago, Los Angeles, the north Okanagan in British Columbia being examples. The change in $\mathrm{PM}_{2.5}$ is associated with climate change alone are relatively small (compare Fig. 8c and d). The use of current anthropogenic emissions in a warmer future climate thus increases $\mathrm{PM}_{2.5}$ on a regional basis, while the implementation of the RCP 6 emissions would result in a decrease in $\mathrm{PM}_{2.5}$ over large regions, with increases in a small number of urban locations. It should be noted that changes in the frequency and magnitude of forest fires have not been included into the emissions database - these may have a considerable impact on the $\mathrm{PM}_{2.5}$ loading associated with climate change.

The differences in $\mathrm{PM}_{2.5}$ can be further analysed through examination of the individual chemical components of $\mathrm{PM}_{2.5}$ that are resolved by AURAMS, as is shown in Fig. 9. Each row of images in Fig. 9 shows a chemical component of $\mathrm{PM}_{2.5}$. The left column of the figures corresponds to the effect of climate change alone $(\triangle \mathrm{CC})$ for each particle species, the middle column the equivalent difference for the combined effects of climate change and the RCP 6 emissions $(\triangle \mathrm{CE})$, and the final column shows the same information as the first column, re-plotted with the middle column's colour scale to allow a magnitude comparison as above. Figure 9 shows that the decreases in $\mathrm{PM}_{2.5}$ associated with the RCP 6 scenario result from decreases in sulphate (Fig. 9b), ammonium (Fig. 9e) and nitrate (Fig. 9h), as well as minor decreases in primary elemental carbon (Fig. 9n) and primary organic carbon (Fig. 9q). Secondary organic aerosol increases slightly (Fig. 9k), but at a level insufficient to offset the de- creases in concentration of the other species. Figure 9 shows that the increases in $\mathrm{PM}_{2.5}$ in the $\mathrm{CC}$ scenario (left and right columns) result from increases in secondary organic aerosol mass (Fig. 9j, 1). Increases in secondary organic aerosol mass also occur in the CE scenario (Fig. 9k), but are lower in magnitude than the other scenario. Both future scenarios have the same biogenic emissions - these are a function of the temperature and, for isoprene, the photosynthetically active radiation levels. These are identical in the two scenarios since both have the same future climate. Consequently, the differences in secondary organic aerosol result from differences in the anthropogenic emissions between the two future scenarios. The increase in $\mathrm{PM}_{2.5}$ in the $\mathrm{CC}$ scenario thus results from increases in secondary organic aerosol, while the decreases in the RCP 6 scenario result from decreases in both secondary inorganic and primary particle mass, and from a relatively reduced influence of secondary organic aerosols on the total $\mathrm{PM}_{2.5}$ loading.

The climate-and-AQ changes to the overall reactivity of the atmosphere may be estimated by comparing the model $24 \mathrm{~h}$ average $\mathrm{OH}$ radical concentrations in the lowest model layer, as is shown in Fig. 10. The $\mathrm{OH}$ radical will be affected by local meteorological (incoming solar radiation, cloudiness, water content of the atmosphere) and chemical factors, hence Fig. 10a is very spatially inhomogeneous. Figure $10 \mathrm{~b}$ shows that the $\mathrm{CC}$ values of $\mathrm{OH}$ decrease relative to the Current simulation over much of the eastern part of the domain, while increasing in the cities and over the prairie regions of Canada and the US and parts of the Rockies in the US. The CE scenario (Fig. 10c) shows a relatively more substantial decrease in $\mathrm{OH}$ concentrations over much of the US and Canada (compare Fig. 10c and d). The latter decreases are 


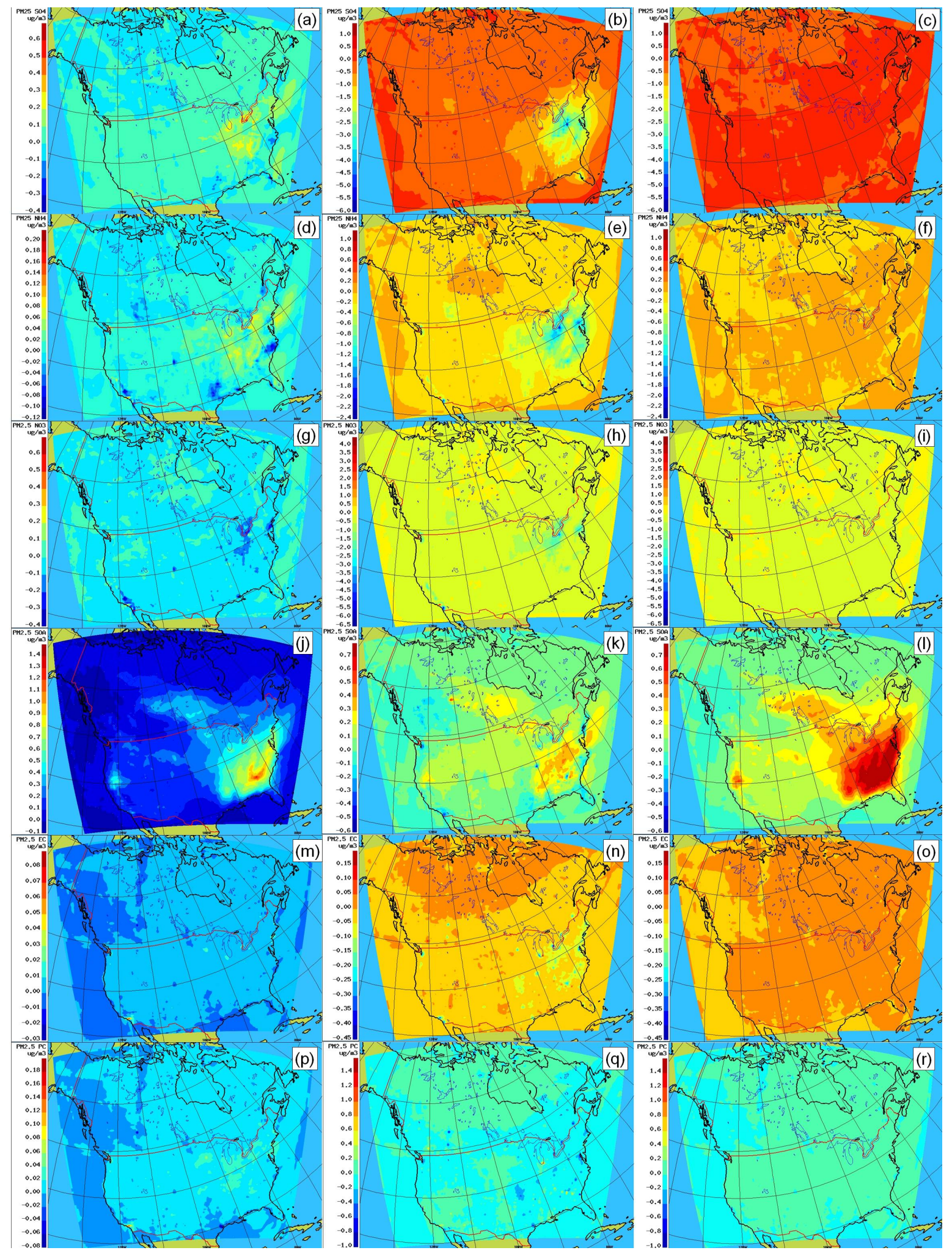

Fig. 9. Chemical speciation of differences in $10 \mathrm{yr}$ average summer particle mass, Future-Current, for the two future scenarios. (a) $\mathrm{PM} 2.5$ $\mathrm{SO}_{4}: \Delta$ CC. (b) $\mathrm{PM}_{2.5} \mathrm{SO}_{4}: \Delta$ CE. (c) $\mathrm{PM}_{2.5} \mathrm{SO}_{4}: \Delta$ CC, with the colour scale of $\Delta$ CE. (d, e, f) $\mathrm{PM}_{2.5} \mathrm{NH}_{4}$, as in (a, b, c). (g, h, i) $\mathrm{PM}_{2.5}$ $\mathrm{NO}_{3}$, as in $(\mathbf{a}, \mathbf{b}, \mathbf{c})$. (j, $\left.\mathbf{k}, \mathbf{l}\right) \mathrm{PM}_{2.5}$ secondary organic aerosol, as in $(\mathbf{a}, \mathbf{b}, \mathbf{c}) .(\mathbf{m}, \mathbf{n}, \mathbf{o}) \mathrm{PM}_{2.5}$ Elemental Carbon, as in $(\mathbf{a}, \mathbf{b}, \mathbf{c}) .(\mathbf{p}, \mathbf{q}, \mathbf{r}) \mathrm{PM}_{2.5}$ primary organic aerosol, as in $(\mathbf{a}, \mathbf{b}, \mathbf{c})$. 


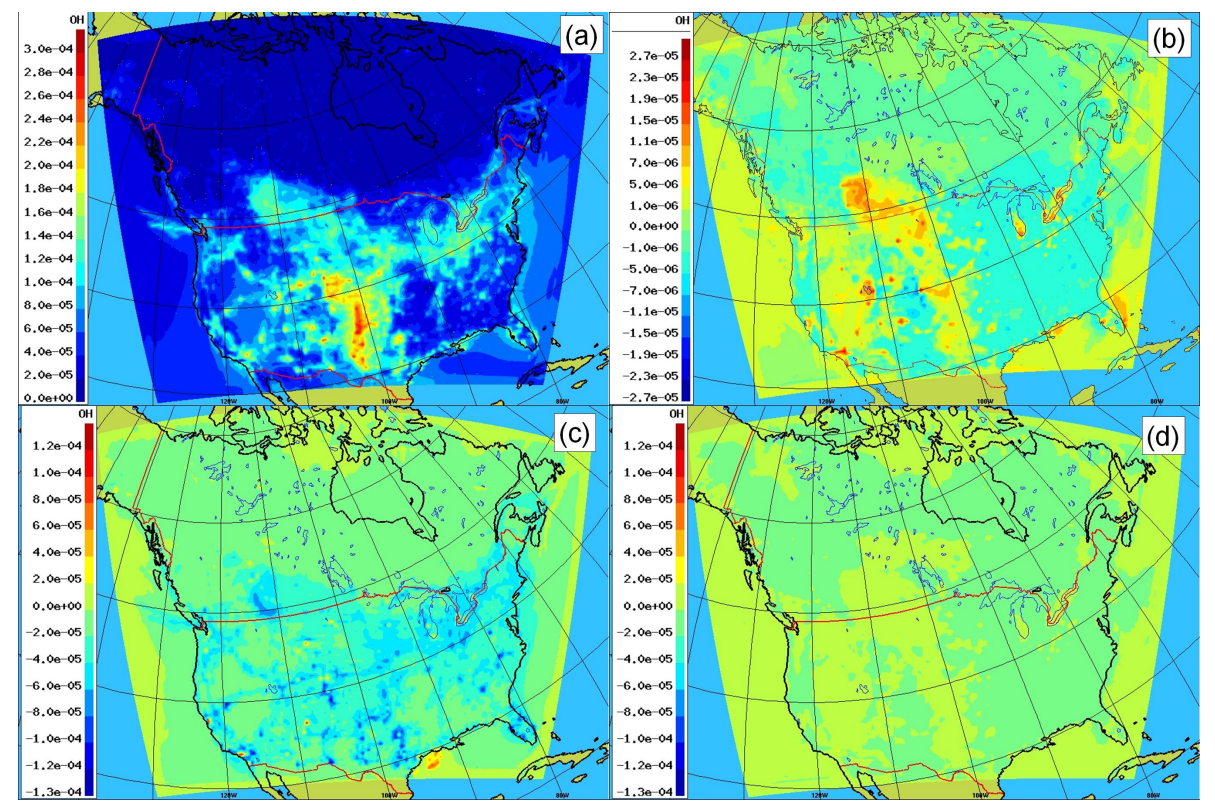

Fig. 10. As in Fig. 7, daily average $\mathrm{OH}$ (units ppbv).

sometimes a significant fraction of the $\mathrm{OH}$ present at specific locations. For regions where biogenic hydrocarbons are important for near-surface atmospheric chemistry, the increases in biogenic emissions under future climate conditions will suppress $\mathrm{OH}$ and this effect will become larger for future climate with the reduced $\mathrm{NO}_{\mathrm{x}}$ emissions specified for the RCP 6 future emissions. We note however that the $\mathrm{OH}$ changes analyzed here are for the lowest model layer and will emphasize the effects of changes in the emissions of short-lived species. The RCP 6 (Fig. 10c) atmosphere has become less reactive, less oxidizing, than the 2002/1999 emissions atmosphere. This may account for some of the other changes noted above, such as the reduction in secondary organic aerosol differences going from CC to CE. Lelieveld et al. (2008) also note that under low $\mathrm{NO}_{\mathrm{x}}$ conditions and in regions of high biogenic emissions (the Amazon), significant $\mathrm{OH}$ recycling from $\mathrm{HO}_{2}$ reactions with carbonyl radicals may take place. This process is missing from the mechanism used here. The magnitude of the $\mathrm{OH}$ decreases noted here should be considered upper limits.

The above chemical analysis shows that changes to air quality due to climate change alone, with anthropogenic emissions remaining constant at 2002 levels, would have a negative impact - with increases in $\mathrm{O}_{3}$ and $\mathrm{PM}_{2.5}$. The analysis also shows that a much more significant impact on air-quality would occur with the enactment of RCP 6 emissions reductions: $\mathrm{O}_{3}$ and $\mathrm{PM}_{2.5}$ levels would decrease over much of North America, and the average $\mathrm{OH}$ concentration of the atmosphere would decrease (the decreases shown here may be an upper limit; cf. Lelieveld et al., 2008). The activity changes of RCP 6 designed to reduce greenhouse gases would thus have a significant co-benefit by reducing partic- ulate matter and ozone concentrations over much of North America.

\section{Model predictions: the effects of climate change on air-quality-induced human health}

The Air-Quality Health Index (AQHI) is a three pollutant health metric designed by Health Canada in conjunction with Environment Canada, to convey the effects of air pollution on acute human health outcomes to the general public (Stieb et al., 2008). The AQHI is a function of three chemical species $\left(\mathrm{O}_{3}, \mathrm{PM}_{2.5}\right.$ and $\left.\mathrm{NO}_{2}\right)$, which are related via Eq. (1):

$$
\begin{aligned}
& \mathrm{AQHI}=\frac{100}{1.04}\left\{\left[e^{8.71 \times 10^{-4}\left[\mathrm{NO}_{2}\right]}-1\right]+\left[e^{5.37 \times 10^{-4}\left[\mathrm{O}_{3}\right]}-1\right]\right. \\
& \left.\quad+\left[e^{4.87 \times 10^{-4}\left[\mathrm{PM}_{2.5}\right]}-1\right]\right\}
\end{aligned}
$$

In the above formula, the concentrations of $\mathrm{NO}_{2}$ and $\mathrm{O}_{3}$ are in units of ppbv, and the concentration of $\mathrm{PM}_{2.5}$ is in $\mu \mathrm{g} \mathrm{m}^{-3}$.

The model-predicted AQHI values for each scenario were calculated on an hourly basis for Canadian cities and towns and major cities within the USA. These values were used to construct box-and-whisker histograms for each of the selected cities (Figs. 11, 12 and 13). Each city's AQHI values for each scenario are represented by a set of three histograms; at left, in blue, "Current", middle, in red, CC, and at right, in green, $\mathrm{CE}$.

The general tendency of Figs. 11 through 13 is a worsening AQHI compared to current conditions (blue) for the $\mathrm{CC}$ scenario (red), and an improvement to AQHI when going to the CE scenario (green), for the metrics displayed. 


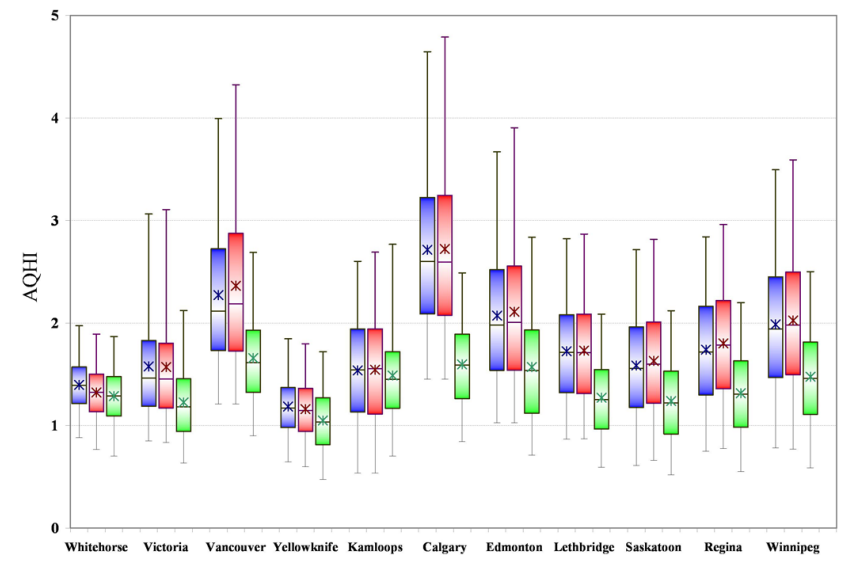

Fig. 11. Air Quality Health Index box-and-whisker histograms, western Canadian towns and cities. Blue: "Current". Red: CC. Green: CE. Upper and lower whisker limits are 98th and 2nd percentiles, respectively, box limits are 75 th and 25 th percentile, median is solid horizontal bar, mean is * symbol.

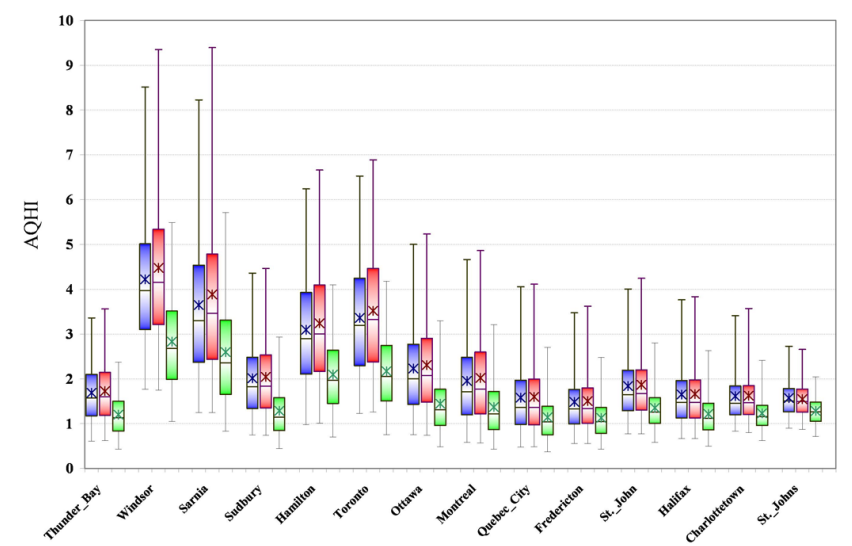

Fig. 12. As in Fig. 11, eastern Canadian towns and cities. Note the vertical scale change compared to Fig. 11.

Local differences may however be noted. For Whitehorse, Yellowknife, (Fig. 11), St. John's (Fig. 12), San Antonio, Dallas, Phoenix and Houston (Fig. 13) both future climates improve (i.e. decrease) the 98th percentile AQHI compared to the current climate. However, for these cities, the RCP 6 scenario results in lower AQHI for all metrics displayed than the CC scenario. Kamloops (Fig. 11) has worse 98th percentile and 2nd percentile AQHI when going from the CC to the $\mathrm{CE}$ scenario, but the median, mean, and 75th percentile values improve. In general, however, the net effect of the RCP 6 emissions changes is a positive one, with decreases in mean, median, and percentile AQHI, while the CC result in increases in the mean, median, and/or extreme AQHI. The climate-change-induced effect of air-quality changes on human health is thus a deterioration: increases in mortality can be expected due to worsening air pollution conditions as a result of climate change, if anthropogenic emissions remain at

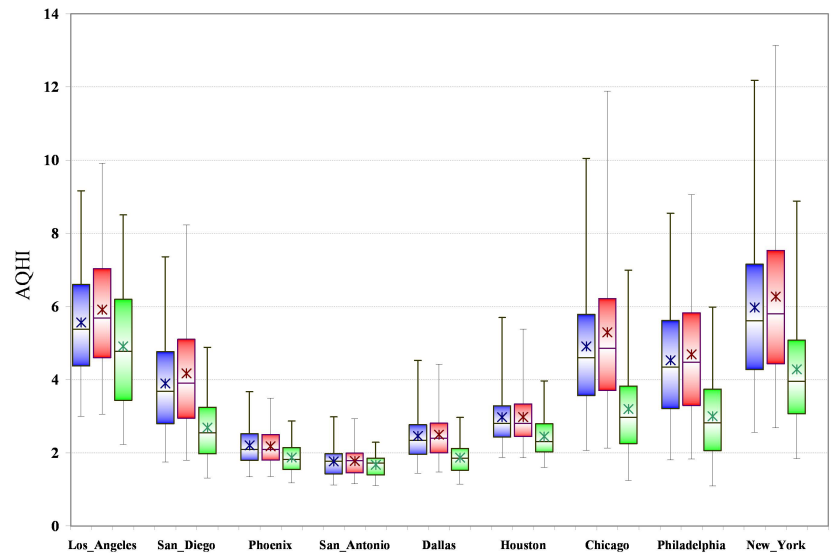

Fig. 13. As in Fig. 11, large American cities. Note the vertical scale change relative to Figs. 11, 12 .

their current levels. Conversely, that effect would be substantially reduced and usually reversed if the RCP 6 emissions controls were enacted.

The analysis gives similar results for other cities in North America - with the implication that mortality resulting from exposure to air pollution can be expected to become slightly worse than at present due to climate change, but would become significantly better, despite climate change, if the RCP 6 emissions reductions were carried out. The cause of the impacts varies from city to city. For example, Los Angeles experiences increases in $\mathrm{O}_{3}$ in the future scenarios, but the decreases in $\mathrm{NO}_{\mathrm{x}}$ and $\mathrm{PM}_{2.5}$ in that location are sufficient to result in net $\mathrm{AQHI}$ decreases. This illustrates the importance of using a multi-pollutant health indicator such as the $\mathrm{AQHI}$ in order to determine the overall impact of emissions changes on mortality. Similar findings for the effect of future climate on air-quality-induced human health impacts have been found in other studies (increases in emergency department visits (Sheffield et al., 2011), mortality and premature death rates, Chang et al., 2010; Jackson et al., 2010; Selin et al., 2009). The timescale of impacts is worth considering in this regard: the effects of reductions of greenhouse gas emissions on climate change may require decades following enactment before a beneficial impact may be seen. - However, if those greenhouse gas emissions reductions are accompanied by reductions in smog precursor emissions, significant health benefits would occur. The latter would take place essentially immediately.

\section{Model predictions: the effects of climate change on ecosystem damag}

\subsection{Sulphur and nitrogen deposition}

An area of ongoing concern is the potential for acidifying precipitation to damage ecosystems. One measure of the 


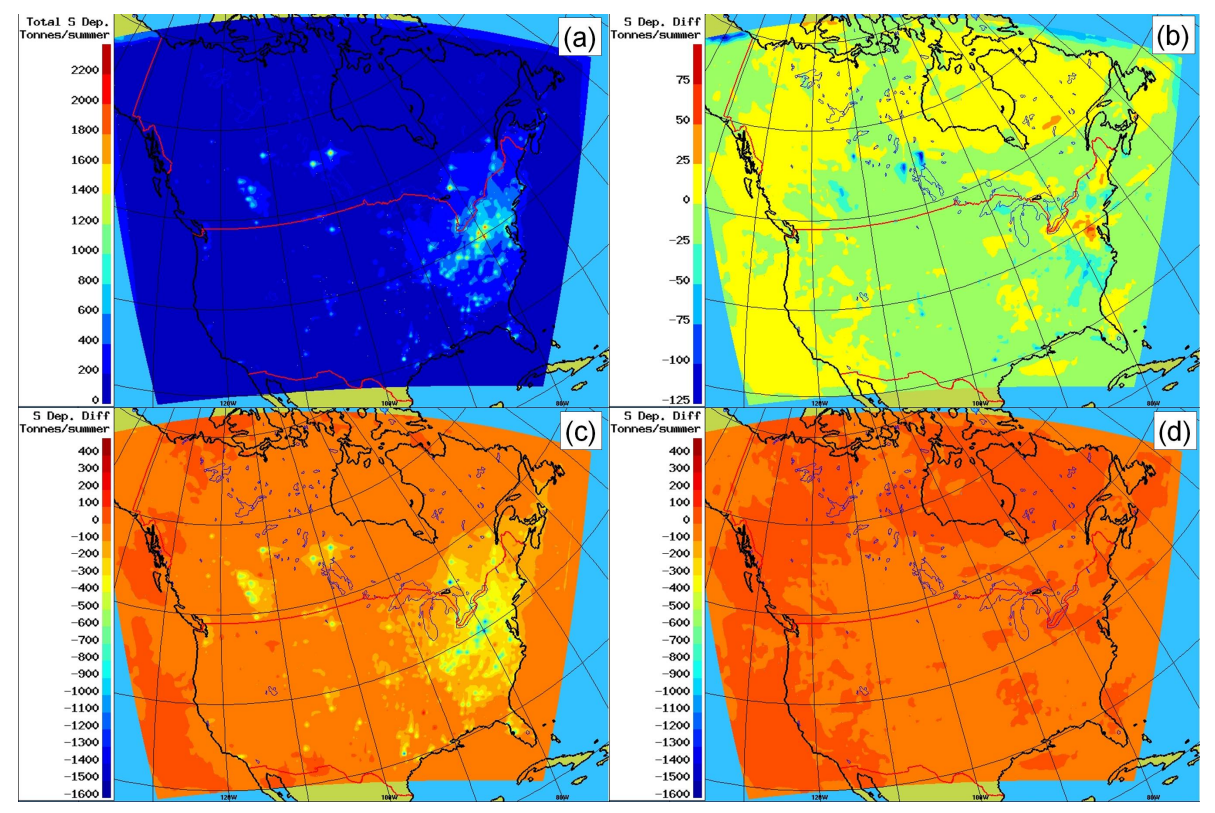

Fig. 14. Change in total deposition of Sulphur. Panels as in Fig. 7, for total S deposition, tonnes/summer.

level of the ability of an ecosystem to withstand acidifying deposition is the "critical load", in which the biological and physical characteristics of an ecosystem are used to estimate the limits of sulphur and nitrogen deposition to that ecosystem, beyond which ecosystem damage occurs (Makar et al., 2009). Unfortunately, many of the underlying assumptions in critical load calculations are temperature dependent, and de facto depend on climate. For that reason, the discussion here will be limited to changes in total sulphur and nitrogen deposition associated with the two future climate scenarios.

Figure 14 shows the model-predicted total sulphur (S) deposition between the two future scenarios and the current climate scenario in a format similar to Fig. 7. Figure 14a shows that relatively minor changes to the total $\mathrm{S}$ deposition occur due to climate change alone, with both increases and decreases of a magnitude smaller than for the current climate (Fig. 14a). Much more substantial decreases occur with CE (Fig. 14c; compare scales with Fig. 14b, d). The RCP 6 scenario has large decreases in deposited sulphur throughout eastern North America, and in specific regions in western North America (Alberta, Seattle-Vancouver corridor, Alberta Oil Sands, Los Angeles).

The effect of RCP 6 on nitrogen deposition (Fig. 15) is, however, shown to be both positive and negative. Over the larger region (most of North America), $\mathrm{N}$ deposition decreases by between 0 to 200 tonnes/summer, and by over 700 tonnes/summer in some parts of the eastern seaboard and over southern Ontario. However, local increases in N deposition also occur, in some of the cities in Canada and the USA. These differences are analysed in more detail, below.

Figure 16 shows the two main contributions to the change in total S deposition: the largest contribution results from de- creases in the dry deposition of gaseous $\mathrm{SO}_{2}$ (Fig. 16a) and the second most important is a decrease in the wet deposition of $\mathrm{SO}_{4}^{2-}(\mathrm{aq})$ in rainwater (Fig. 16b). Many of the emissions changes associated with RCP 6 reduce sulphur-emitting activities (e.g. coal-fired power-plants), hence these changes might be expected. Particulate sulphate has a relatively minor impact on the changes to sulphur deposition, as does wet deposition of the $\mathrm{HSO}_{3}^{-}(\mathrm{aq})$ ion, and gas-phase $\mathrm{H}_{2} \mathrm{SO}_{4}$ deposition (not shown).

Figure 17 shows the main contributions to the change in $\mathrm{N}$ : the largest contribution creating increases in $\mathrm{N}$ deposition is wet deposition of $\mathrm{NH}_{4}^{+}$(aq) (Fig. 17a), followed by dry deposition of gaseous $\mathrm{NH}_{3}$ (Fig. 17b). The decreases in $\mathrm{N}$ deposition in the Seattle-Vancouver corridor, the southern Great Lakes, and the eastern seaboard of the USA result from decreases in the wet deposition of $\mathrm{NO}_{3}^{-}(\mathrm{aq})(\mathrm{Fig}$. 17c). Figure 18 shows the driving factor behind some of these differences: concentrations of gaseous ammonia are expected to increase in some regions, under RCP 6 (Fig. 18c). The CC simulation (Fig. 18b) shows slight increases in concentration, which are a response to the meteorological changes associated with the future climate. Gaseous ammonia emissions are expected to increase in RCP 6 by approximately $30 \%$ relative to the current emissions levels (Fig. 2b). This results in additional ammonia being taken up into cloud water and deposited in rainfall (Fig. 17a), and dry deposited in gaseous form (Fig. 17b). The $\mathrm{NO}_{\mathrm{x}}$ emissions reductions associated with RCP 6 (Fig. 2b) in turn reduce the production of nitric acid, thus reducing the wet deposition of the nitrate ion (Fig. 17c). Similarly, the $\mathrm{SO}_{2}$ emissions reductions of RCP 6 (Fig. 2b) reduce the dry deposition of $\mathrm{SO}_{2}$ (Fig. 16a), and the wet deposition of the sulphate ion (Fig. 16b). 


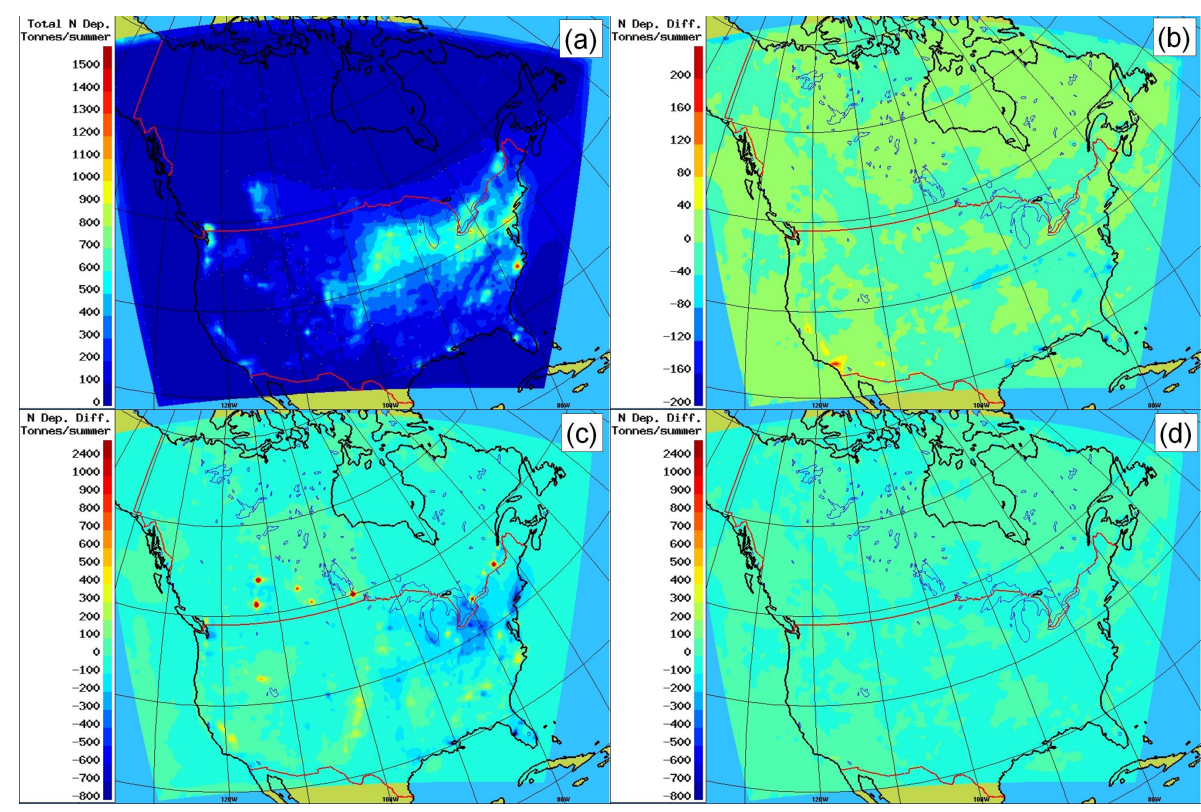

Fig. 15. Change in total deposition of N. Panels as in Fig. 7, for total $\mathrm{N}$ deposition, tonnes/summer.

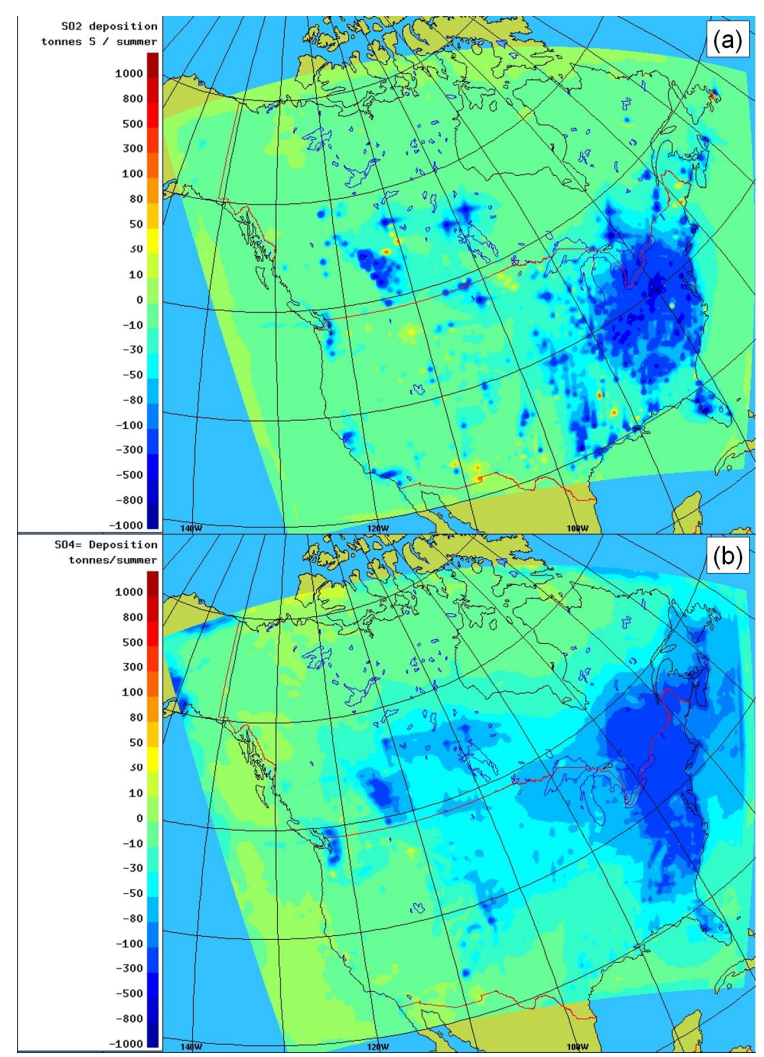

Fig. 16. Two main contributors to changes in $\mathrm{S}$ deposition $\triangle \mathrm{CE}$, Tonnes/summer. (a) Dry Deposition of gaseous $\mathrm{SO}_{2}$, (b) Wet deposition of $\mathrm{SO}_{4}^{2-}(\mathrm{aq})$. Note that positive and negative scales have a logarithmic interval.
Ammonia emissions are expected to increase to a greater or lesser degree in all of the RCP scenarios. The implication of these findings is that some ammonia gas emissions reductions, beyond the projections used in the RCP scenarios, may be required in order to prevent local increases in deposited nitrogen.

\subsection{Ozone deposition}

The deposition of ozone to vegetated surfaces has long been linked to foliage damage, and is implicated in reductions of crop yields (Averny et al., 2011). Ten year average summer ozone deposition and difference fields are shown in Fig. 19. Small magnitude increases and decreases in deposited ozone occur for the CC scenario (Fig. 18b) relative to current conditions (Fig. 19a), while the ozone decreases of Fig. 7c result in substantial reductions in ozone deposition over the eastern US and south-eastern Ontario and Quebec. The adoption of RCP 6 emissions controls would therefore lead to reductions in ozone deposition relative to current conditions, and hence lead to improvements in crop yields as the result of reduced ozone exposure to foliage.

\section{Conclusions}

The analysis presented above was designed to answer two main questions, "What is the impact of climate change on air-quality (all other aspects of the system being held constant)?", and "What is the impact of reducing anthropogenic precursor emissions in a warmer future climate?". The questions have been asked in the context of air pollutant concentrations, human health, and environmental degradation. The 


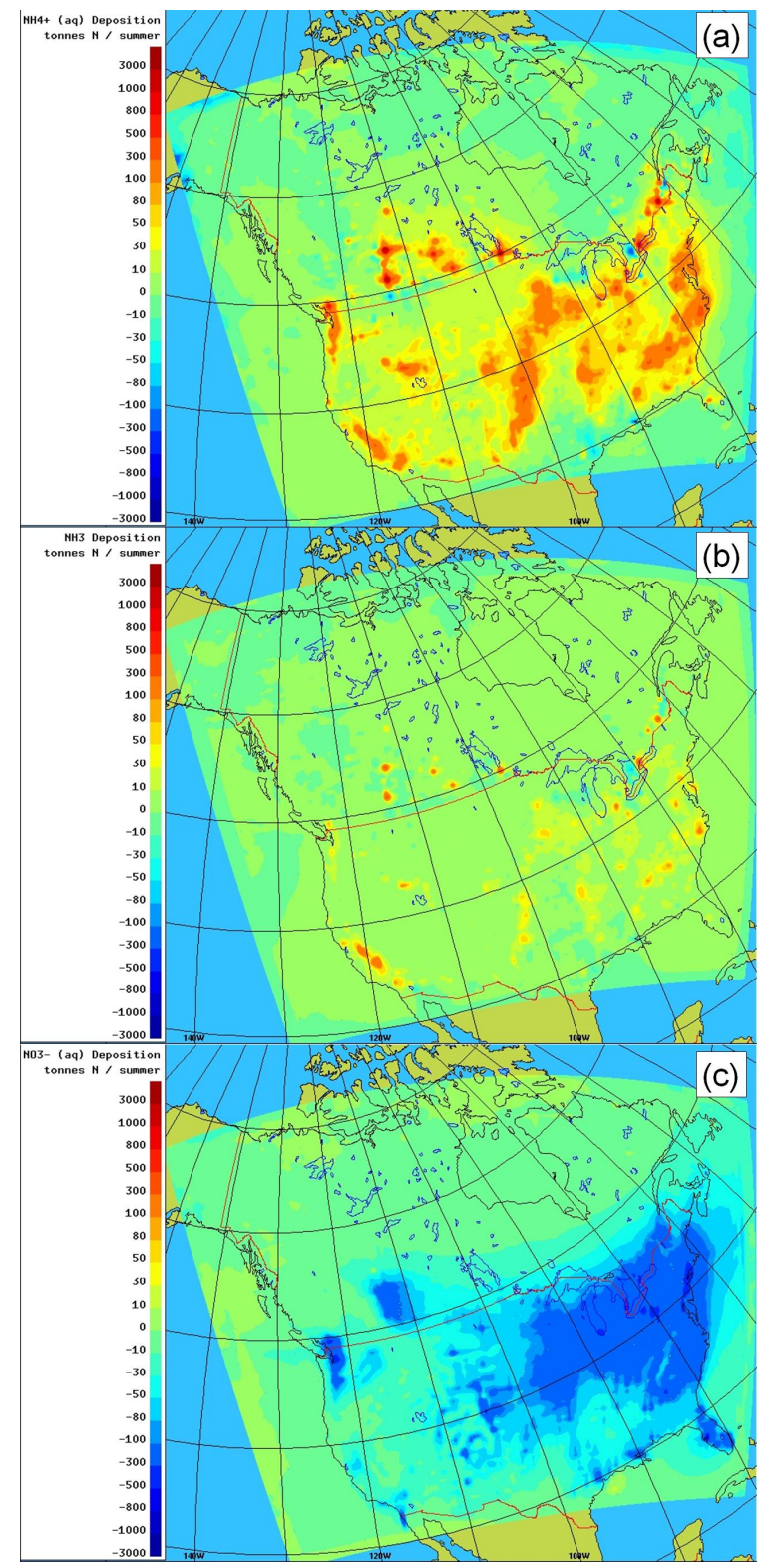

Fig. 17. Three main contributors to changes in $\mathrm{N}$ deposition $\triangle \mathrm{CE}$, tonnes/summer. (a) Wet deposition of $\mathrm{NH}_{4}^{+}$(aq). (b) Dry deposition of gaseous $\mathrm{NH}_{3}$. (c) Wet deposition of $\mathrm{NO}_{3}^{-}$(aq). Note that positive and negative scales have a logarithmic interval.

overview answers to these questions, as suggested by our analysis, are as follows.

The impact of climate change on air-quality when all other model constraints remain unchanged, is one of degradation, though variable in extent and location. When current anthropogenic pollutant precursor emissions are used in our modelling system with an SRES A2 climate for 2041 to 2050 , ozone and $\mathrm{PM}_{2.5}$ concentrations increase, the airquality health index scores increase (indicating increased mortality for vulnerable individuals within the human popu- lation), acidifying deposition increases, as does ozone deposition. The differences are typically on the order of increases of a few ppbv for ozone, few $\mu \mathrm{g} \mathrm{m}^{-3}$ for $\mathrm{PM}_{2.5}$, though larger differences may sometimes be locally discerned.

The impact of reducing anthropogenic precursor emissions according to the IPCC's RCP 6 in a warmer future climate is one of improvement, more significant in magnitude and opposite in direction to the other future scenario, though once again variable in extent and location. Concentrations of ground-level ozone decrease significantly throughout southern Canada and the most of the USA, with large decreases (in excess of $20 \mathrm{ppbv}$ ) in the US eastern seaboard. $\mathrm{PM}_{2.5}$ decreases of more than $8 \mu \mathrm{g} \mathrm{m}^{-3}$ are predicted. Air quality health index histograms indicate that most cities would experience reductions in air-pollution-induced mortality. Deposition of acidifying sulphur would decrease, and deposition of acidifying nitrogen would decrease over much of the eastern seaboard. Increases in acidifying nitrogen were predicted to occur in some areas, since the RCP 6 emissions scenario assumes that ammonia gas emissions will increase. Deposition of ozone to vegetated surfaces will also decrease significantly, by a substantial fraction of the total ozone deposition predicted to occur under current climate conditions.

Both of these sets of changes are relative to current climate conditions. The RCP 6 scenario thus represents a significant improvement to ambient air quality, human and ecosystem health, compared to that currently experienced in North America. If anthropogenic precursor emissions remain fixed at their current values, then the impact of climate change acting alone will be to worsen air-quality. The magnitude of the deterioration will be less than the magnitude of the potential improvements associated with the RCP 6 emissions scenarios.

The results have important implications for public policymaking. While the impacts of greenhouse gas emissions reductions may take several decades to be discerned, the benefits resulting from reducing the emissions of air pollutants and their precursors would be immediate. Our results suggest that worsening air quality due to climate change alone would be offset or reversed through emission reductions such as those embodied in the RCP 6 projections. The study raises the possibility that actions which simultaneously reduce both greenhouse gases and air pollution precursors may result in further improvements to air-quality, beyond those investigated here. The benefits in reducing air pollution as shown here include reductions in mortality associated with acute airquality episodes, in acidifying deposition, and in ozone deposition (improving crop yields), over much of North America. These potential benefits may offset some of the costs associated with greenhouse gas mitigation strategies, and further investigation of this possibility is therefore recommended. 


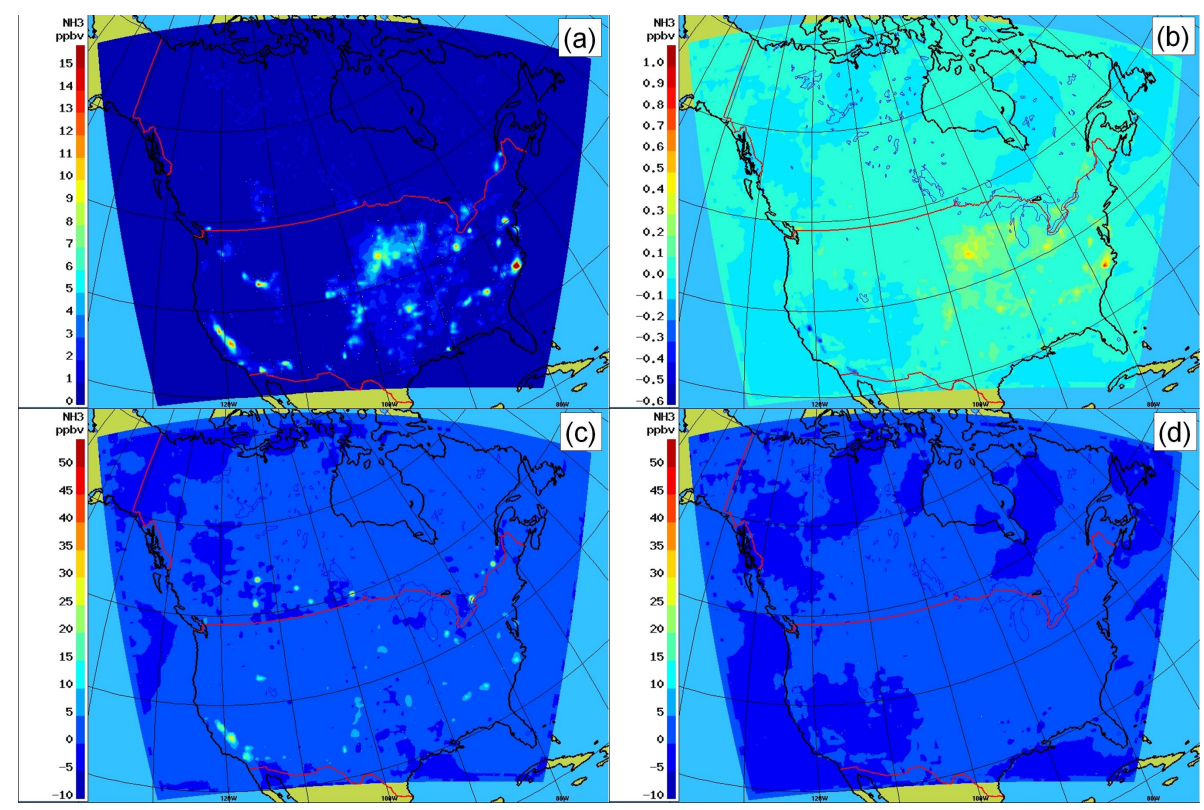

Fig. 18. Change in summer average $\mathrm{NH}_{3}$ concentration. Panels as in Fig. 6, but for $\mathrm{NH}_{3}$ (ppbv).

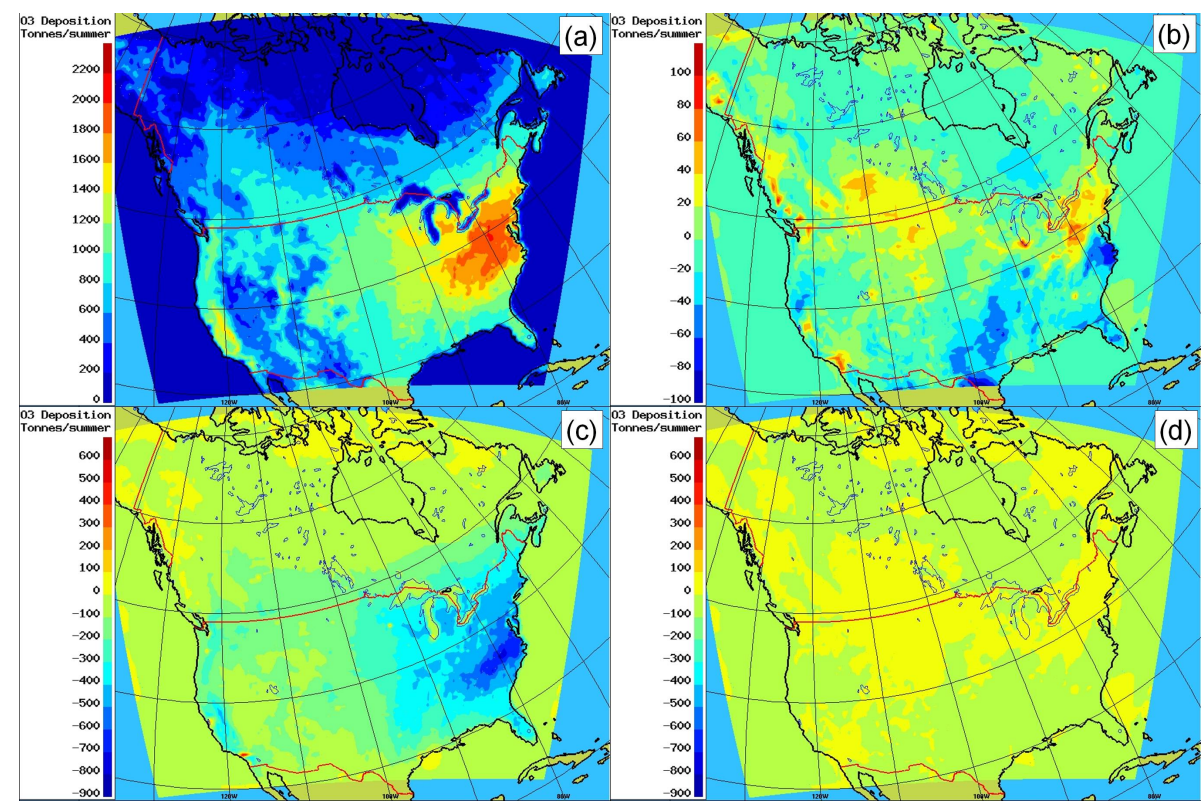

Fig. 19. Change in summer average $\mathrm{O}_{3}$ deposition. Panels as in Fig. 6, but for $\mathrm{O}_{3}$ deposition (tonnes/summer).

Acknowledgements. The authors acknowledge the following contributions to this work: Junhua Zhang, Qiong Zheng, Michael Moran: SMOKE emissions processing for future and current emissions scenarios. Philip Cheung: programming support. Wyatt Freeman, Ted Yan, Parth Dalwadi: undergraduate co-op student programming support. The authors thank Environment Canada's Clean Air Regulatory Agenda and the Ouranos Consortium for financial support. We also acknowledge the invaluable contribution of the Ouranos Climate Simulation Group to the long-term development and maintenance of the CRCM that made this project possible as well as for their help with the simulations used here.
Edited by: J. West

\section{References}

Averny, S., Mauszerall, D. L., Liu, J., and Horowitz, L. W.: Global crop yield reductions due to surface ozone exposure: 2. Year 2030 potential crop production losses and economic damage under two scenarios of $\mathrm{O}_{3}$ pollution, Atmos. Environ., 45, 22972309, 2011.

Avise, J., Chen, J., Lamb, B., Wiedinmyer, C., Guenther, A., Salathé, E., and Mass, C.: Attribution of projected changes 
in summertime US ozone and $\mathrm{PM}_{2.5}$ concentrations to global changes, Atmos. Chem. Phys., 9, 1111-1124, doi:10.5194/acp9-1111-2009, 2009.

Bechtold, P., Bazile, E., Guichard, F., Mascart, P., and Richard, E.: A mass flux convection scheme for regional and global models, Q. J. Roy. Meteorol. Soc., 127, 869-886, 2001.

Bell, M. L., Goldberg, R., Hogrefe, C., Kinney, P. L., Knowlton, K., Lynn, B., Rosenthal, J., Rosenzweig, C., and Patz, J. A.: Climate change, ambient ozone, and health in 50 US cities, Climatic Change, 82, 61-76, 2007.

Brasseur, G. P., Schultz, M., Granier, C., Saunois, M., Diehl, T., Botzet, M., Roeckner, E., and Walters, S.: Impact of climate change on the future chemical composition of the global troposphere, J. Climate, 19, 3932-3951, 2006.

Briggs, G. A.: Plume rise and buoyancy effects, in: Atmospheric Science and Power Productions, edited by: Randerson, D. J., DOE/PIC-27601, Technical Information Center, US DOE, Oak Ridge, TN, 327-366, 1984.

Briggs, G. A.: Analytical parameterizations of diffusion: the convective boundary layer, J. Clim. Appl. Meteorol., 24, 1167-1186, 1985.

Caya, D. and Laprise, R.: A semi-implicit semi-Lagrangian regional climate model: The Canadian RCM, Mon. Weather Rev., 127, 341-362, 1999.

CEP: Carolina Environmental Program, Sparse Matrix Operator Kernel Emission (SMOKE) modelling system, University of North Carolina, Carolina Environmental Programs, Chapel Hill, NC, see http://www.smoke-model.org/index.cfm, 2003.

Chang, H. H., Zhou, J., and Fuentes, M.: Impact of climate change on ambient ozone level and mortality in Southeastern United States, Int. J. Env. Res. Public Health, 7, 2866-2880, 2010.

Chen, J., Avise, J., Guenther, A., Wiedinmyer, C., Salathe, E., Jackson, R. B., and Lamb, B.: Future land use and land cover influences on regional biogenic emissions and air quality in the United States, Atmos. Environ., 43, 5771-5780, 2009a.

Chen, J., Avise, J., Lamb, B., Salathé, E., Mass, C., Guenther, A., Wiedinmyer, C., Lamarque, J.-F., O'Neill, S., McKenzie, D., and Larkin, N.: The effects of global changes upon regional ozone pollution in the United States, Atmos. Chem. Phys., 9, 11251141, doi:10.5194/acp-9-1125-2009, 2009b.

Cheng, C. S., Campbell, M., Li, Q., Li, G., Auld, H., Day, N., Pengelly, D., Gingrich, S., and Yap, D.: A synoptic climatological approach to assess climatic impact on air quality in south-central Canada. Part II: Future estimates, Water Air Soil Pollut., 182, 117-130, 2007.

Cheng, C. S., Campbell, M., Li, Q., Auld, H., Day, N., Pengelly, D., Gingrich, S., Klaassen, J., MacIver, D., Comer, N., Mao, Y., Thompson, W., and Lin, H.: Differential and combined impacts of extreme temperatures and air pollution on human mortality in south-central Canada. Part II: Future estimates, Air Quality, Atmosphere and Health, 2, 223-235, 2009.

Civerolo, K., Hogrefe, C., Lynn, B., Rosenthal, J., Ku, J., Solecki, W., Cox, J., Small, C., Rosenzweig, C., Goldberg, R., Knowlton, K., and Kinney, P.: Estimating the effects of increased urbanization on surface meteorology and ozone concentrations in the New York City metropolitan region, Atmos. Env., 41, 18031818, 2007.

CMOS: Canadian Meteorological and Oceanographic Society, 2007, Statement on Climate Change, Canadian Meteorological and Oceanographic Society Bulletin, 35, 99-106, 2007.

Côté, J., Gravel, S., Méthot, A., Patoine, A., Roch, M., and Staniforth, A.: The operational CMC-MRB Global Environmental Multiscale (GEM) model. Part 1: Design considerations and formulation, Mon. Weather Rev., 126, 1373-1395, 1998.

Dave, J. V.: Development of programs for computing characteristics of ultraviolet radiation, Final Report under Contract NAS 5-21680, NASA Report CR-139134, National Aeronautics and Space Administration, Goddard Space Flight Center, Greenbelt, Maryland, NTIS \# N75-10746/6SL, 27 pp., 1972.

Davies, H. C.: A lateral boundary formulation for multilevel prediction models, Q. J. Roy. Meteor. Soc., 102, 405-418, 1976.

Dawson, J. P., Adams, P. J., and Pandis, S. N.: Sensitivity of ozone to summertime climate in the eastern USA: A modelling case study, Atmos. Environ., 41, 1494-1511, 2007.

DeMore, W. B., Sander, S. P., Molina, M. J., Golden, D. M., Hampson, R. F., Kurylo, M. J., Howard, C. J., and Ravishankara, A. R.: Chemical Kinetics and Photochemical Data for Use in Stratospheric Modeling, Evaluation Number 8, National Aeronautics and Space Administration, Jet Propulsion Laboratory, California Institute of Technology, Pasadena, California, 266 pp., 1988.

Demuzere, M. and van Lipzig, N. P. M.: A new method to estimate air-quality levels using a synoptic-regression approach. Part I: Present-day $\mathrm{O}_{3}$ and $\mathrm{PM}_{10}$ analysis, Atmos. Environ., 44, 13411355, 2010a.

Demuzere, M. and van Lipzig, N. P. M.: A new method to estimate air-quality levels using a synoptic-regression approach. Part II: Future $\mathrm{O}_{3}$ concentrations, Atmos. Environ., 44, 1356-1366, $2010 b$.

Engardt, M.: Modelling of near-surface ozone over South Asia, J. Atmos. Chem., 59, 61-80, 2008.

Fiore, A. M., Levy II, H., and Jaffe, D. A.: North American isoprene influence on intercontinental ozone pollution, Atmos. Chem. Phys., 11, 1697-1710, doi:10.5194/acp-11-1697-2011, 2011.

Flato, G. M., Boer, G. J., Lee, W. G., McFarlane, N. A., Ramsden, D., Reader, M. C., and Weaver, A. J.: The Canadian Centre for Climate Modeling and Analysis Global Coupled Model and its climate, Clim. Dynam., 16, 451-467, 2000.

Forkel, R. and Knoche, R.: Regional climate change and its impact on photooxidant concentrations in southern Germany: Simulations with a coupled regional climate-chemistry model, J. Geophys. Res.-Atmos., 111, D12302, doi:10.1029/2005JD006748, 2006.

Forkel, R. and Knoche, R.: Nested regional climate-chemistry simulations for central Europe, Compt. Rendus Geosci., 339, 734746, 2007.

Fujino, J., Nair, R., Kainuma, M., Masui, T., and Matsuoka, Y.: Multigas mitigation analysis on stabilization scenarios using AIM global model, Multigas Mitigation and Climate Policy. The Energy Journal Special Issue, 343-354, 2006.

Fung, C. S., Misra, P. K., Bloxam, R., and Wong, S.: A numerical experiment on the relative importance of $\mathrm{H}_{2} \mathrm{O}_{2}$ and $\mathrm{O}_{3}$ in aqueous conversion of $\mathrm{SO}_{2}$ to $\mathrm{SO}_{4}^{2-}$, Atmos. Environ., 25A, 411423, 1991.

Gal-Chen, T. and Sommerville, R. C.: On the use of a coordinate transformation for the solution of Navier-Stokes, J. Comput. Phys., 17, 209-228, 1975.

Gent, P. R., Bryan, F. O., Danabasoglu, G., Doney, S. C., Holland, W. R., Large, W. G., and McWilliams, J. C.: The NCAR climate 
system model global ocean component, J. Climate, 11, 12871306, 1998.

Gong, S. L., Barrie, L. A., and Lazare, M.: Canadian Aerosol Module (CAM): A size-segregated simulation of atmospheric aerosol processes for climate and air quality models 2 . Global sea-salt aerosol and its budgets, J. Geophys. Res., 107, 4779, doi:10.1029/2001JD002004, 2003a.

Gong, S. L., Barrie, L. A., Blanchet, J.-P., von Salzen, K., Lohmann, U., Lesins, G., Spacek, L., Zhang, L. M., Girard, E., Lin, H., Leaitch, R., Leighton, H., Chylek, P., and Huang, P.: Canadian Aerosol Module: A size-segregated simulation of atmospheric aerosol processes for climate and air quality models. 1. Module development, J. Geophys. Res., 108, 4007, doi:10.1029/2001JD002002, 2003b.

Gong, W., Dastoor, A. P., Bouchet, V. S., Gong, S. L., Makar, P. A., Moran, M. D., Pabla, B., Menard, S., Crevier, L.-P., Cousineau, S., and Venkatesh, S.: Cloud processing of gases and aerosols in a regional air quality model (AURAMS), Atmos. Res., 82, 248275, 2006.

Hijioka, Y., Matsuoka, Y., Nishimoto, H., Masui, M., and Kainuma, M.: Global GHG emissions scenarios under GHG concentration stabilization targets, Journal of Global Environmental Engineering, 13, 97-108, 2008.

Hogrefe, C., Lynn, B., Civerolo, K., Ku, J.-Y., Rosenthal, J., Rosenzweig, C., Goldberg, R., Gaffin, S., Knowlton, K., and Kinney, P. L.: Simulating changes in regional air pollution over the eastern United States due to changes in global and regional climate and emissions, J. Geophys. Res., 109, D22301, doi:10.1029/2004JD004690, 2004.

Houyoux, M. R., Vukovich, J. M., Coats Jr., C. J., and Wheeler, N. J. M.: Emission inventory development and processing for the Seasonal Model for Regional Air Quality (SMRAQ) project, J. Geophys. Res., 105, 9079-9090, 2000.

Intergovernmental Panel on Climate Change (IPCC): Special Report on Emissions Scenarios, edited by: Nacenovic, N. and Swart, R., Cambridge Univ. Press, New York, 612 pp., 2000. Intergovernmental Panel on Climate Change (IPCC): Summary for Policymakers, in: Climate Change 2007: The Physical Science Basis. Contribution of Working Group I to the Fourth Assessment Report of the Intergovernmental Panel on Climate Change, edited by: Solomon, S., Qin, D., Manning, M., Chen, Z., Marquis, M., Averyt, K. B., Tignor, M., and Miller, H. L., Cambridge University Press, Cambridge, 12-17, 2007.

Jacob, D. J. and Winner, D. A.: Effect of climate change on air quality, Atmos. Environ., 43, 51-63, 2009.

Jackson, J. E., Yost, M. G., Karr, C., Fitzpatrick, C., Lamb, B. K, Chung, S. H., Chen, J., Avise, J., Rosenblatt, R. A., and Fenske, R. A.: Public health impacts of climate change in Washington State: Projected mortality risks due to heat events and air pollution, Climate Change, 102, 159-186, 2010.

Jacobson, M. Z. and Streets, D. B.: Influence of future anthropogenic emissions on climate, natural emissions, and air quality, J. Geophys. Res., 114, D08118, doi:10.1029/2008JD011476, 2009.

Kain, J. S. and Fritsch, J. M.: A one-dimensional entraining/detraining plume model and its implication in convective parameterization, J. Atmos. Sci., 47, 2784-2802, 1990.

Kawase, H., Nagashima, T., Sudo, K., and Nozawa, T.: Future changes in tropospheric ozone under Representative Con- centration Pathways (RCPs), Geophy. Res. Lett., 38, L05801, doi:10.1029/2010GL046402, 2011.

Kelly, J., Makar, P. A., and Plummer, D. A.: Projections of mid-century summer air-quality for North America: effects of changes in climate and precursor emissions, Atmos. Chem. Phys. Discuss., 12, 3875-3940, doi:10.5194/acpd-12-38752012, 2012.

Kuhn, M., Builtjes, P. J. H., Poppe, D. Simpson, D., Stockwell, W. R., Andersson-Skoeld, Y., Baart, A., Das, M., Fiedler, F., Hov, O., Kirchner, F., Makar, P. A., Milford, J. B., Roemer, M. G. M., Ruhnke, R., Strand, A., Vogel, B., and Vogel, H.: Intercomparison of the Gas-Phase Chemistry in Several Chemistry and Transport Models, Atmos. Environ., 32, 693-709, 1998.

Lam, Y. F., Fu, J. S., Wu, S., and Mickley, L. J.: Impacts of future climate change and effects of biogenic emissions on surface ozone and particulate matter concentrations in the United States, Atmos. Chem. Phys., 11, 4789-4806, doi:10.5194/acp-11-47892011, 2011.

Laprise, R., Caya, D., Frigon, A., and Paquin, D.: Current and perturbed climate as simulated by the second-generation Canadian Regional Climate Model (CRCM-II) over northwestern North America, Clim. Dynam., 21, 405-421, 2003.

Lelieveld, J., Butler, T. M., Crowley, J. N., Dillon, T. J., Fischer, H., Ganzeveld, L., Harder, H., Lawrence, M. G., Martinez, M., Taraborrelli, D., and Williams, J.: Atmospheric oxidation capacity sustained by a tropical forest, Nature, 452, 737-740, doi:10.1038/nature06870, 2008.

Leung, L. R. and Gustafson Jr., W. I.: Potential regional climate change and implications to U.S. air quality, Geophys. Res. Lett, 32, L16711, doi:10.1029/2010GL046402, 2005.

Liao, H., Seinfeld, J. H., Adams, P. J., and Mickley, L. J.: Global radiative forcing of coupled tropospheric ozone and aerosols in a unified general circulation model, J. Geophys. Res.-Atmos., 109, D16207, doi:10.1029/2003JD004456, 2004.

Liao, H., Chen, W.-T., and Seinfeld, J. H.: Role of climate change in global predictions of future tropospheric ozone and aerosols, J. Geophys. Res.-Atmos., 111, D12304, doi:10.1029/2005JD006852, 2006.

Liao, H., Henze, D. K., Seinfeld, J. H., Wu, S., and Mickley, L. J.: Biogenic secondary organic aerosol over the United States: Comparison of climatological simulations with observations, J. Geophys. Res.-Atmos., 112, D06201, doi:10.1029/2006JD007813, 2007.

Lin, J.-T, Wuebbles, D. J., Huang, H.-C., Tao, Z., Caughhey, M., Liang, X.-Z., Zhu, J.-H., and Holloway, T.: Potential effects of climate and emissions changes on surface ozone in the Chicago area, J. Great Lakes Res., 36 (supplement 2), 59-64, 2010.

Makar, P. A., Bouchet, V. S., and Nenes, A.: Inorganic Chemistry Calculations using HETV - A Vectorized Solver for the $\mathrm{SO}_{4}^{2-}$ $\mathrm{NO}_{3}^{-}-\mathrm{NH}_{4}^{+}$system based on the ISORROPIA Algorithms, Atmos. Environ., 37, 2279-2294, 2003.

Makar, P. A., Moran, M. D., Zheng, Q., Cousineau, S., Sassi, M., Duhamel, A., Besner, M., Davignon, D., Crevier, L.-P., and Bouchet, V. S.: Modelling the impacts of ammonia emissions reductions on North American air quality, Atmos. Chem. Phys., 9, 7183-7212, doi:10.5194/acp-9-7183-2009, 2009.

Makar, P. A., Zhang, J., Gong, W., Stroud, C., Sills, D., Hayden, K. L., Brook, J., Levy, I., Mihele, C., Moran, M. D., Tarasick, D. W., He, H., and Plummer, D.: Mass tracking for chemical 
analysis: the causes of ozone formation in southern Ontario during BAQS-Met 2007, Atmos. Chem. Phys., 10, 11151-11173, doi:10.5194/acp-10-11151-2010, 2010a.

Makar, P. A., Gong, W., Mooney, C., Zhang, J., Davignon, D., Samaali, M., Moran, M. D., He, H., Tarasick, D. W., Sills, D., and Chen, J.: Dynamic adjustment of climatological ozone boundary conditions for air-quality forecasts, Atmos. Chem. Phys., 10, 8997-9015, doi:10.5194/acp-10-8997-2010, 2010b.

Meehl, G. A., Covey, C., Delworth, T., Latif, M., McAvaney, B., Mitchell, J. F. B., Stouffer, R. J., and Taylor, K. E.: The WCRP CMIP3 Mulitmodel dataset: A new era in climate change research, B. Am. Meteorol. Soc., 88, 1383-1394, 2007.

Mickley, L. J., Jacob, D. J., Field, B. D., and Rind, D.: Climate response to the increase in tropospheric ozone since preindustrial times: A comparison between ozone and equivalent $\mathrm{CO}_{2}$ forcings, J. Geophys. Res.-Atmos., 109, D05106, doi:10.1029/2003JD003653, 2004a.

Mickley, L. J., Jacob, D. J., Field, B. D., and Rind, D.: Effects of future climate change on regional air pollution episodes in the United States, Geophys. Res. Lett., 31, L24103, doi:10.1029/2004GL021216, 2004b.

Mladjic, B., Sushama, L., Khaliq, M. N., Laprise, R., Caya, D., and Roy, R.: Canadian RCM projected changes to extreme precipitation characteristics over Canada, J. Climate, 24, 2565-2584, 2011.

Murazaki, K. and Hess, P.: How does climate change contribute to surface ozone change over the United States?, J. Geophys. Res.Atmos., 111, D05301, doi:10.1029/2005JD005873, 2006.

Murphy, J. M., Sexton, D. M. H., Barnett, D. N., Jones, G. S., Webb, M. J., Collins, M., and Stainforth, D. A.: Quantification of modelling uncertainties in a large ensemble of climate change simulations, Nature, 430, 768-772, 2004.

Odum, J. R., Jungkamp, T. P. W., Griffin, R. J., Flagan, R. C., and Seinfeld, J. H.: The atmospheric aerosol-forming potential of whole gasoline vapour, Science, 276, 96-99, 1996.

Peterson, J. T.: Calculated actinic fluxes $(290-700 \mathrm{~nm})$ for air pollution photochemistry applications, US Environmental Protection Agency Report Number EPA-600/4-76-025, 55 pp., 1976.

Pierce, T., Geron, C., Bender, L., Dennis, R., Tonneson, G., and Guenther, A.: Influence of increased isoprene emissions on regional ozone modeling, J. Geophys. Res., 103, 25611-25629, 1998.

Plummer, D. A., Caya, D., Frigon, A., Cote, H., Gigurere, M., Paquin, D., Biner, S., Harvey, R., and de Elia, R.: Climate and climate change over North America as simulated by the Canadian RCM, J. Climate, 19, 3112-3132, 2006.

Racherla, P. N. and Adams, P. J.: Sensitivity of Global Tropospheric Ozone and Fine Particulate Matter Concentrations to Climate Change, J. Geophys. Res., 111, D24103, doi:10.1029/2005JD006939, 2006.

Racherla, P. N. and Adams, P. J.: The response of surface ozone to climate change over the Eastern United States, Atmos. Chem. Phys., 8, 871-885, doi:10.5194/acp-8-871-2008, 2008.

Racherla, P. N. and Adams, P. J.: U.S. ozone air quality under changing climate and anthropogenic emissions, Environ. Sci. Technol., 43, 571-577, 2009.

RCP Database: http://www.iiasa.ac.at/web-apps/tnt/RcpDb/dsd? Action=htmlpage \&page=compare, last access: 18 May 2012.
Richtmyer, R. D.: Difference methods for initial value problems, Krieger Pub. Co., Malabar, Fla., 405 pp., 1994.

Riette, S. and Caya, D.: Sensitivity of short simulations to the various parameters in the new CRCM spectral nudging, in: Research Activities in Atmospheric and Oceanic Modelling, edited by: Ritchie, H., WMO/TD-No. 1105, Rep. 32, 7.39-7.40, 2002.

Scinocca, J. F. and McFarlane, N. A.: The parameterization of drag induced by stratified flow over anisotropic orography, Q. J. Roy. Meteor. Soc., 126, 2353-2393, 2000.

Scinocca, J. F., McFarlane, N. A., Lazare, M., Li, J., and Plummer, D.: Technical Note: The CCCma third generation AGCM and its extension into the middle atmosphere, Atmos. Chem. Phys., 8, 7055-7074, doi:10.5194/acp-8-7055-2008, 2008.

Selin, N. E., Wu, S., Nam, K. M., Reilly, J. M., Paltsev, S., Prinn, R. G., and Webster, M. D.: Global health and economic impacts of future ozone pollution, Environ. Res. Lett., 4, 044014, doi:10.1088/1748-9326/4/4/044014, 2009.

Sharf, G., Pleg, M., Livnat, M., and Luria, M.: Plume rise measurements from large point sources in Israel, Atmos. Environ., 27A, 1657-1663, 1993.

Sheffield, P. E., Knowlton, K., Carr, J. L., and Kinney, P. L.: Modeling of regional climate change effects on ground-level ozone and childhood asthma, Am. J. Preventative Med., 41, 251-257, 2011.

Smolarkiewicz, P. K. and Pudykiewicz, J. A.: A class of semiLagrangian approximations for fluids, J. Atmos. Sci., 49, 20822096, 1992.

Stainforth, D. A., Aina, T., Christensen, C., Collins, M., Faull, N., Frame, D. J., Kettleborough, J. A., Knight, S., Martin, A., Murphy, J. M., Piani, C., Sexton, D., Smith, L. A., Spicer, R. A., Thorpe, A. J. and Allen, M. R.: Uncertainty in predictions of the climate response to rising levels of greenhouse gases, Nature, 433, 403-406, doi:10.1038/nature03301, 2005.

Steiner, A. L., Tonse, S., Cohen, R. C., Goldstein, A. H., and Harley, R. A.: Influence of future climate and emissions on regional air quality in California, J. Geophys. Res.-Atmos., 111, D18303, doi:10.1029/2005JD006935, 2006.

Stella, P., Personne, E., Loubet, B., Lamaud, E., Ceschia, E., Béziat, P., Bonnefond, J. M., Irvine, M., Keravec, P., Mascher, N., and Cellier, P.: Predicting and partitioning ozone fluxes to maize crops from sowing to harvest: the Surfatm- $\mathrm{O}_{3}$ model, Biogeosciences, 8, 2869-2886, doi:10.5194/bg-8-2869-2011, 2011.

Stieb, D. M., Burnett, R. T., Smith-Doiron, M., Brion, O., Hwashin, H. S., and Economou, V.: A new multipollutant, no-threshold air quality health index based on short-term associations observed in daily time-series analyses, J. Air Waste Manage., 58, 435-450, 2008.

Stevenson, D. S., Dentener, F. J., Schultz, M. G., Ellingsen, K., van Noije, T. P. C., Wild, O., Zeng, G., Amann, M., Atherton, C. S., Bell, N., Bergmann, D. J., Bey, I., Butler, T., Cofala, J., Collins, W. J., Derwent, R. G., Doherty, R. M., Drevet, J., Eskes, H. J., Fiore, A. M., Gauss, M., Hauglustaine, D. A., Horowitz, L. W., Isaksen, I. S. A., Krol, M. C., Lamarque, J.-F., Lawrence, M. G., Montanaro, V., Müller, J.-F., Pitari, G., Prather, M. J., Pyle, J. A., Rast, S., Rodriguez, J. M., Sanderson, M. G., Savage, N. H., Shindell, D. T., Strahan, S. E., Sudo, K., and Szopa, S.: Multimodel ensemble simulations of present-day and near-future tropospheric ozone, J. Geophys. Res.-Atmos., 111, D08301, doi:10.1029/2005JD006338, 2006. 
Stockwell, W. R. and Lurmann, F. W.: Intercomparison of the ADOM and RADM gas-phase chemical mechanisms. Electrical Power Research Institute Topical Report, Electrical Power Research Institute, 3412 Hillview Avenue, Palo Alto, CA, 401 pp., 1989.

Sushama, L., Khaliq, M. N., and Laprise, R.: Dry spell characteristics over Canada in a changing climate as simulated by the Canadian RCM, Global Planet. Change, 74, 1-14, 2010.

Tagaris, E., Manomaiphiboon, K., Liao, K.-J., Leung, L. R., Woo, J.-H., He, S., Amar, P., and Russell, A. G.: Impacts of global climate change and emissions on regional ozone and fine particulate matter concentrations over the United States, J. Geophys. Res., 112, D14312, doi:10.1029/2006JD008262, 2007.

Tagaris, E., Liao, K.-J., Manomaiphiboon, K., He, S., Woo, J.-H., Amar, P., and Russell, A. G.: The role of climate and emission changes in future air quality over southern Canada and northern Mexico, Atmos. Chem. Phys., 8, 3973-3983, doi:10.5194/acp-83973-2008, 2008.

Tagaris, E., Liao, K.-J., Delucia, A. J., Deck, L., Amar, P., and Russell, A. G.: Potential impact of climate change on air pollutionrelated human health effects, Environ. Sci. Technol., 43, 49794988, 2009.

Tagaris, E., Liao, K.-J., DeLucia, A. J., Deck, L., Amar, P., and Russell, A. G.: Sensitivity of air pollution-induced premature mortality to precursor emissions under the influence of climate change, Int. J. Env. Res. Public Health, 7, 2222-2237, 2010.

Timbal, B., Fernandez, E., and Li, Z.: Generalization of a statistical downscaling model to provide local climate change projections for Australia, Environ. Modell. Softw., 24, 341-358, 2009.

Turner, D. B.: Proposed pragmatic methods for estimating plume rise and plume penetration through atmospheric layers, Atmos. Environ., 19, 1215-1218, 1985.

US EPA: Assessment of the impacts of global change on regional US air quality: a synthesis of climate change impacts on groundlevel ozone. An Interim Report of the US EPA Global Change Research Program, National Center for Environmental Assessment, Washington, DC; EPA/600/R-07/094F, available from the National Technical Information Service, Springfield, VA, and online at: http://www.epa.gov/ncea, 2009.
Van Dingenen, R., Dentener, F. J., Raes, F., Krol, M. C., Emberson, L., and Cofala, J.: The global impact of ozone on agricultural crop yields under current and future air quality legislation, Atmos. Environ., 43, 604-618, 2009.

Venkatram, A., Karamchandani, P. K., and Misra, P. K.: Testing a comprehensive acid deposition model, Atmos. Environ., 22, 737-747, 1988.

Verseghy, D. L.: The Canadian Land Surface Scheme (CLASS): Its history and future, Atmosphere-Ocean, 38, 1-13, 2000.

Wise, E. K.: Climate-based sensitivity of air quality to climate change scenarios for the southwestern United States, Int. J. Climatol., 29, 87-97, 2009.

Wu, S., Mickley, L. J., Jacob, D. J., Logan, J. A., Yantosca, R. M., and Rind., D.: Why are there large differences between models in global budgets of tropospheric ozone?, J. Geophys. Res.-Atmos., 112, D05302, doi:10.1029/2006JD007801, 2007.

Wu, S., Mickley, L. J., Leibensperger, E. M., Jacob, D. J., Rind, D., and Streets, D. G.: Effects of 2000-2050 global change on ozone air quality in the United States, J. Geophys. Res., 113, D06302, doi:10.1029/2007JD008917, 2008a.

Wu, S., Mickley, L. J., Jacob, D. J., Rind, D., and Streets, D. G.: Effects of 2000-2050 changes in climate and emissions on global tropospheric ozone and the policy-relevant background surface ozone in the United States, J. Geophys. Res.-Atmos., 113, D18312, doi:10.1029/2007JD009639, 2008 b.

Young, T. R. and Boris, J. P.: A numerical technique for solving stiff ordinary differential equations associated with the chemical kinetics of reactive-flow problems, J. Phys. Chem., 81, 2424 2427, 1977.

Zhang, G. J. and McFarlane, N. A.: Sensitivity of climate simulations to the parameterization of cumulus convection in the CCCGCM, Atmos. Ocean, 3, 407-446, 1995.

Zhang, L., Gong, S. L., Padro, J., and Barrie, L.: A Size-segregated Particle Dry Deposition Scheme for an Atmospheric Aerosol Module, Atmos. Environ., 35, 549-560, 2001. 